Atmos. Chem. Phys., 18, 17515-17527, 2018

https://doi.org/10.5194/acp-18-17515-2018

(c) Author(s) 2018. This work is distributed under

the Creative Commons Attribution 4.0 License.

\title{
Nitrate formation from heterogeneous uptake of dinitrogen pentoxide during a severe winter haze in southern China
}

\author{
Hui Yun ${ }^{1}$, Weihao Wang ${ }^{1}$, Tao Wang ${ }^{1}$, Men Xia ${ }^{1}$, Chuan Yu ${ }^{1,2}$, Zhe Wang ${ }^{1}$, Steven C. N. Poon ${ }^{1}$, Dingli Yue ${ }^{3}$, and \\ Yan Zhou $^{3}$ \\ ${ }^{1}$ Department of Civil and Environmental Engineering, The Hong Kong Polytechnic University, Hong Kong, China \\ ${ }^{2}$ Environment Research Institute, Shandong University, Jinan, China \\ ${ }^{3}$ Guangdong Environmental Monitoring Center, State Environmental Protection Key Laboratory \\ of Regional Air Quality Monitoring, Guangzhou, China
}

Correspondence: Tao Wang (cetwang@polyu.edu.hk)

Received: 10 July 2018 - Discussion started: 6 August 2018

Revised: 20 November 2018 - Accepted: 25 November 2018 - Published: 11 December 2018

\begin{abstract}
Nitrate $\left(\mathrm{NO}_{3}^{-}\right)$has become a major component of fine particulate matter $\left(\mathrm{PM}_{2.5}\right)$ during hazy days in China. However, the role of the heterogeneous reactions of dinitrogen pentoxide $\left(\mathrm{N}_{2} \mathrm{O}_{5}\right)$ in nitrate formation is not well constrained. In January 2017, a severe haze event occurred in the Pearl River Delta (PRD) of southern China during which high levels of $\mathrm{PM}_{2.5}\left(\sim 400 \mu \mathrm{g} \mathrm{m}^{-3}\right)$ and $\mathrm{O}_{3}(\sim 160 \mathrm{ppbv})$ were observed at a semi-rural site (Heshan) in the western PRD. Nitrate concentrations reached $108 \mu \mathrm{g} \mathrm{m}^{-3}$ (1 h time resolution), and the contribution of nitrate to $\mathrm{PM}_{2.5}$ was nearly $40 \%$. Concurrent increases in $\mathrm{NO}_{3}^{-}$and $\mathrm{ClNO}_{2}$ (with a maximum value of $8.3 \mathrm{ppbv}$ at a $1 \mathrm{~min}$ time resolution) were observed in the first several hours after sunset, indicating an intense $\mathrm{N}_{2} \mathrm{O}_{5}$ heterogeneous uptake by aerosols. The formation potential of $\mathrm{NO}_{3}^{-}$via $\mathrm{N}_{2} \mathrm{O}_{5}$ heterogeneous reactions was estimated to be between 29.0 and $77.3 \mu \mathrm{g} \mathrm{m}^{-3}$ in the early hours ( 2 to $6 \mathrm{~h}$ ) after sunset based on the measurement data, which could completely explain the measured increase in the $\mathrm{NO}_{3}^{-}$concentration during the same time period. Daytime production of nitric acid from the gasphase reaction of $\mathrm{OH}+\mathrm{NO}_{2}$ was calculated with a chemical box model built using the Master Chemical Mechanism (MCM v3.3.1) and constrained by the measurement data. The integrated nocturnal nitrate formed via $\mathrm{N}_{2} \mathrm{O}_{5}$ chemistry was comparable to or even higher than the nitric acid formed during the day. This study confirms that $\mathrm{N}_{2} \mathrm{O}_{5}$ heterogeneous chemistry was a significant source of aerosol nitrate during hazy days in southern China.
\end{abstract}

\section{Introduction}

Severe haze in China has been a major concern of the regulatory and scientific communities in recent years. Nitrate has also been identified as an important component of $\mathrm{PM}_{2.5}$ during hazy days in both summer and winter (e.g., Huang et al., 2014; Li et al., 2018; Pathak et al., 2009; Zhang et al., 2015). Moreover, the proportion of nitrate in $\mathrm{PM}_{2.5}$ has steadily increased over the last decade due to the lagged control of $\mathrm{NO}_{x}$ emissions compared to $\mathrm{SO}_{2}$ (Fu et al., 2014; Geng et al., 2017; Qu et al., 2017; Reuter et al., 2014; X. Wang et al., 2016). As a result, the concentrations of nitrate in $\mathrm{PM}_{2.5} / \mathrm{PM}_{1.0}$ have been even higher than those of sulfate during some haze events (Ge et al., 2017; Li et al., 2017; Liu et al., 2015; Yang et al., 2017; Yue et al., 2015).

Nitrate is formed from $\mathrm{NO}_{x}$ during both the daytime and nighttime. During the day, nitric acid $\left(\mathrm{HNO}_{3}\right)$ is produced through the gas-phase reaction between $\mathrm{OH}$ and $\mathrm{NO}_{2}(\mathrm{Re}-$ action R1), while this pathway is insignificant at night due to very low $\mathrm{OH}$ concentrations (e.g., Seinfeld and Pandis, 2016). Nitric acid can react with ammonia $\left(\mathrm{NH}_{3}\right)$ to form ammonium nitrate $\left(\mathrm{NH}_{4} \mathrm{NO}_{3}\right)$, and an equilibrium can be reached for these three compounds between the gas phase and the particle phase (Reactions R2, R3). During nighttime, the heterogeneous uptake of $\mathrm{N}_{2} \mathrm{O}_{5}$, which is formed from reactions involving $\mathrm{O}_{3}, \mathrm{NO}_{2}$, and $\mathrm{NO}_{3}$, becomes a source of nitrate and also produces gaseous $\mathrm{ClNO}_{2}$ when chloridecontaining aerosol is present (Reactions R4-R7; FinlaysonPitts et al., 1989). This nitrate formation pathway is only important at night due to the fast photolysis of $\mathrm{NO}_{3}$ during the 
day. Compared to the relatively well-understood formation of aerosol nitrate via the $\mathrm{OH}+\mathrm{NO}_{2}$ reaction, the contribution from $\mathrm{N}_{2} \mathrm{O}_{5}$ heterogeneous reactions has been poorly quantified due to the limited knowledge of key factors controlling the heterogeneous processes, such as the $\mathrm{N}_{2} \mathrm{O}_{5}$ uptake coefficient $\left(\gamma_{\mathrm{N}_{2} \mathrm{O}_{5}}\right)$ and $\mathrm{ClNO}_{2}$ yield $\left(\phi_{\mathrm{ClNO}_{2}}\right)$ (Brown and Stutz, 2012; Chang et al., 2011).

$$
\begin{aligned}
& \mathrm{OH}+\mathrm{NO}_{2}+\mathrm{M} \rightarrow \mathrm{HNO}_{3}+\mathrm{M} \\
& \mathrm{HNO}_{3}(g)+\mathrm{NH}_{3}(g) \leftrightarrow \mathrm{NH}_{4} \mathrm{NO}_{3}(s) \\
& \mathrm{HNO}_{3}(g)+\mathrm{NH}_{3}(g) \leftrightarrow \mathrm{NH}_{4}^{+}(\mathrm{aq})+\mathrm{NO}_{3}^{-}(\mathrm{aq}) \\
& \mathrm{NO}_{2}+\mathrm{O}_{3} \rightarrow \mathrm{NO}_{3} \\
& \mathrm{NO}_{2}+\mathrm{NO}_{3}+M \leftrightarrow \mathrm{N}_{2} \mathrm{O}_{5}+M \\
& \mathrm{NO}_{3}+\mathrm{VOCs} \rightarrow \text { products } \\
& \mathrm{N}_{2} \mathrm{O}_{5}+\mathrm{H}_{2} \mathrm{O} \text { or } \mathrm{Cl}^{-}(\mathrm{aq}) \\
& \quad \rightarrow(2-\phi) \mathrm{NO}_{3}^{-}(\mathrm{aq})+\phi \mathrm{ClNO}_{2}(g)
\end{aligned}
$$

Model studies initially treated $\gamma_{\mathrm{N}_{2} \mathrm{O}_{5}}$ as a constant $(0.03$ to 0.1) (Dentener and Crutzen, 1993; Makar et al., 1998; Munger et al., 1998; Schaap et al., 2004; Wen et al., 2015; Xue et al., 2014), and later utilized several parameterization schemes of $\gamma_{\mathrm{N}_{2} \mathrm{O}_{5}}$ and $\phi_{\mathrm{ClNO}_{2}}$ based on laboratory investigations of their dependence on aerosol composition and aerosol water content (Anttila et al., 2006; Bertram and Thornton, 2009; Davis et al., 2008; Evans and Jacob, 2005; Riemer et al., 2003, 2009; Roberts et al., 2009). However, recent studies have found a significant discrepancy between the fieldderived and the parameterized $\gamma_{\mathrm{N}_{2} \mathrm{O}_{5}}$ and $\phi_{\mathrm{ClNO}_{2}}$ (McDuffie et al., 2018; Phillips et al., 2016; Tham et al., 2018; X. Wang et al., 2017; Z. Wang et al., 2017; Zhou et al., 2018). These findings suggest that $\mathrm{N}_{2} \mathrm{O}_{5}$ uptake is more complicated than previously thought, and a better understanding of the uptake process is needed to improve the prediction of nitrate and haze.

In addition to the modeling approach, field measurements of trace gases and aerosol composition have been used to infer the contribution of $\mathrm{N}_{2} \mathrm{O}_{5}$ heterogeneous chemistry to nitrate formation. Pathak et al. (2009) postulated the importance of $\mathrm{N}_{2} \mathrm{O}_{5}$ heterogeneous reactions with respect to the high aerosol nitrate observed in Beijing and Shanghai in summertime by examining the variation of nitrate with the change in relative humidity (RH) and the equilibrium between anions and cations in $\mathrm{PM}_{2.5}$. Pathak et al. (2011) further investigated nitrate formation using a coupled aqueous phase radical mechanism (CAPRAM) and a gas-phase chemistry mechanism (RACM, without $\mathrm{ClNO}_{2}$ chemistry). By constraining the uptake coefficient of $\mathrm{N}_{2} \mathrm{O}_{5}$ in the range from 0.001 to 0.1 , they reproduced the observed enhancement of nitrate and suggested that $\mathrm{N}_{2} \mathrm{O}_{5}$ uptake by aerosols contributed to $50 \%$ to $100 \%$ of the nighttime increase in nitrate. A similar method was recently used by Wen et al. (2018) to simulate the summertime nitrate formation in the North China Plain (NCP), which demonstrated the dominant contribution of $\mathrm{N}_{2} \mathrm{O}_{5}$ heterogeneous reactions to night- time nitrate formation. Based on the observed covariation of nitrate and $\mathrm{RH}$, Wang et al. (2009) speculated that $\mathrm{N}_{2} \mathrm{O}_{5}$ reactions dominated the nitrate formation on polluted days with high $\mathrm{NO}_{2}$ and $\mathrm{O}_{3}$ concentrations in Shanghai. Neither $\mathrm{N}_{2} \mathrm{O}_{5}$ nor $\mathrm{ClNO}_{2}$ was measured during these early observationbased studies. A recent study (H. Wang et al., 2017) inferred $\gamma \mathrm{N}_{2} \mathrm{O}_{5}$ from the measured $\mathrm{N}_{2} \mathrm{O}_{5}$ on 4 days in urban Beijing and estimated the lower limit of the formation potential of aerosol nitrate assuming a unity $\phi_{\mathrm{ClNO} 2}$ because $\mathrm{ClNO}_{2}$ was not measured. Their result showed a comparable contribution to nitrate formation from the $\mathrm{N}_{2} \mathrm{O}_{5}$ heterogeneous chemistry and from the daytime pathway of the $\mathrm{OH}+\mathrm{NO}_{2}$ reaction.

In the present study, $\mathrm{N}_{2} \mathrm{O}_{5}, \mathrm{ClNO}_{2}$, and the related chemical and meteorological parameters were measured at a semirural site in the Pearl River Delta of southern China from 2 to 15 January 2017. A severe haze event was observed during the field study with $\mathrm{PM}_{2.5}$ reaching $400 \mu \mathrm{g} \mathrm{m}^{-3}$ and $\mathrm{O}_{3}$ peaking at 160 ppbv. $\mathrm{ClNO}_{2}$, which is only known to be produced from $\mathrm{N}_{2} \mathrm{O}_{5}$ heterogeneous uptake, reached $8.3 \mathrm{ppbv}$, which is the largest reported value to date and revealed extremely active $\mathrm{N}_{2} \mathrm{O}_{5}$ chemistry during the abovementioned episode. The concurrent measurements of $\mathrm{N}_{2} \mathrm{O}_{5}, \mathrm{ClNO}_{2}$, and aerosol nitrate provide better constraints for elucidating nighttime $\mathrm{NO}_{3} / \mathrm{N}_{2} \mathrm{O}_{5}$ chemistry and aerosol nitrate formation. An overview of the measurement data was first presented. The nighttime processes that led to the formation of nitrate (e.g., the production of $\mathrm{NO}_{3}$ and $\mathrm{N}_{2} \mathrm{O}_{5}, \mathrm{~N}_{2} \mathrm{O}_{5}$ uptake coefficient, and $\mathrm{ClNO}_{2}$ yield) were analyzed. The nighttime formation potential of nitrate was estimated based on these data and compared to the measured increase in nitrate. The daytime production of nitric acid via the $\mathrm{OH}+\mathrm{NO}_{2}$ reaction was calculated based on a box model using the Master Chemical Mechanism (MCM v3.3.1) and compared to the nighttime formation potential of nitrate.

\section{Methods}

\subsection{Site description}

The field observation was conducted at the Guangdong atmospheric supersite, a semi-rural site located at Hua Guo Shan (HGS, $22.728^{\circ} \mathrm{N}, 112.929^{\circ} \mathrm{E}$ ) southwest of the city of Heshan from 2 to 15 January 2017. As shown in Fig. 1, HGS is a hill with a height of $60 \mathrm{~m}$ a.s.l. All measurement instruments were located on the fourth floor of a four-story building on the top of the hill. The observation site was located in the western PRD where the economic activity and population density are much lower than the central PRD. There are five main roads near the HGS site, including three national roads (G325, G94, and G15), and two provincial roads (S272 and S270). The hill is covered by subtropical trees and surrounded by similar hills within close proximity; a few residents live at the foot of the hill, and there is some farmland in the area. 

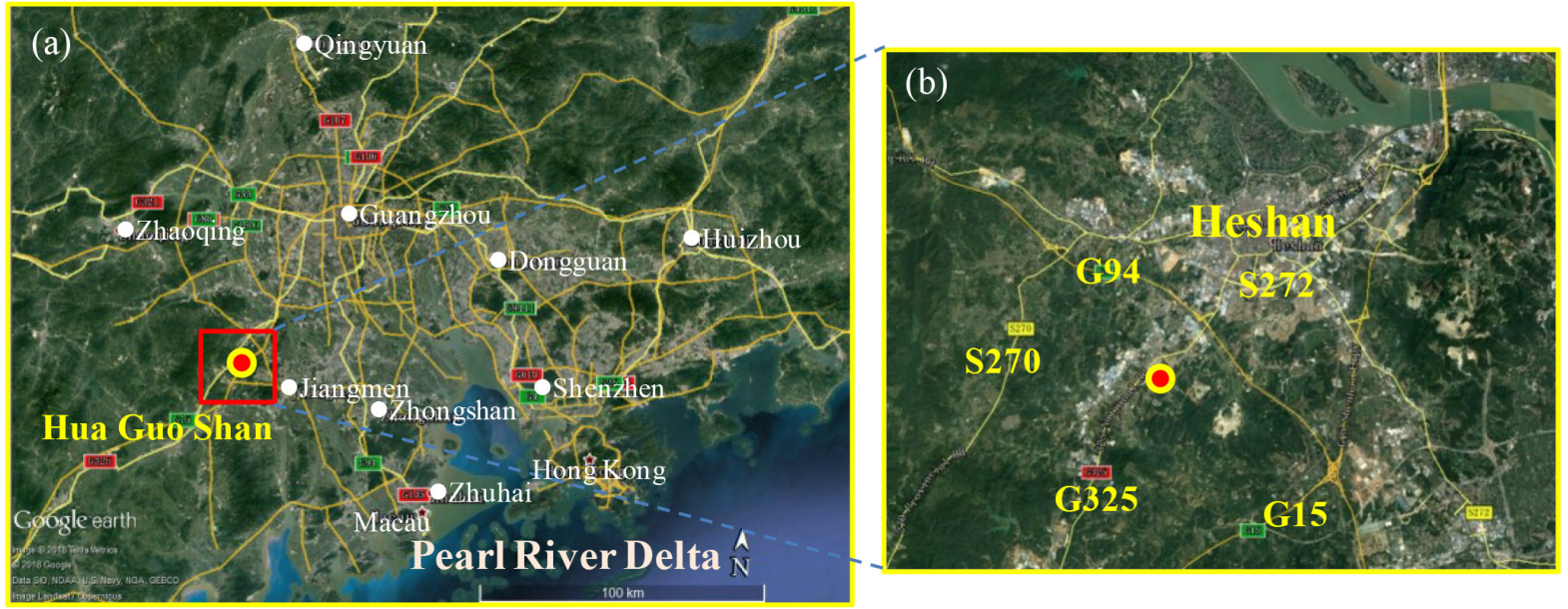

Figure 1. (a) Google map images of the Pearl River Delta in Guangdong Province and the measurement site (Hua Guo Shan). (b) The topography and major roads (shown by number) adjacent to the measurement site.

\subsection{Chemical ionization mass spectrometer}

$\mathrm{N}_{2} \mathrm{O}_{5}$ and $\mathrm{ClNO}_{2}$ were simultaneously observed using a quadrupole chemical ionization mass spectrometer (CIMS, THS Instruments, Atlanta). The same instrument had been used in several previous studies in southern and northern China (Tham et al., 2016; T. Wang et al., 2016; Z. Wang et al., 2017). The reader can refer to these earlier papers for a detailed description of the measurement principle, calibration, and maintenance procedures. Briefly, ambient $\mathrm{N}_{2} \mathrm{O}_{5}$ and $\mathrm{ClNO}_{2}$ are converted to ion clusters of $\left.\mathrm{I}_{(} \mathrm{N}_{2} \mathrm{O}_{5}\right)^{-}$and $\mathrm{I}\left(\mathrm{ClNO}_{2}\right)^{-}$by Iodide ions $\left(\mathrm{I}^{-}\right)$that are produced by exposing $\mathrm{CH}_{3} \mathrm{I} / \mathrm{N}_{2}(0.3 \% v / v)$ to an alpha radioactive source, 210Po, and are subsequently detected at 235 and $208 \mathrm{mz}^{-1}$, respectively. Activated carbon packed in a filter was used to determine the instrument background, which were $10.2 \pm 2.2$ and $8.9 \pm 2.0 \mathrm{~Hz}$ on average for $\mathrm{N}_{2} \mathrm{O}_{5}$ and $\mathrm{ClNO}_{2}$, respectively. In situ offline calibration was carried out every day for $\mathrm{N}_{2} \mathrm{O}_{5}$ and every 2 days for $\mathrm{ClNO}_{2}$ by mixing the respective synthetic standard into humidified zero air (with RH controlled at $60 \%$ in the present study). The $\mathrm{N}_{2} \mathrm{O}_{5}$ standard was generated by reacting excess $\mathrm{NO}_{2}$ with $\mathrm{O}_{3}$ and determined from the decrease of $\mathrm{NO}_{2}$, and the $\mathrm{ClNO}_{2}$ was synthesized by the uptake of a known concentration of $\mathrm{N}_{2} \mathrm{O}_{5}$ on a $\mathrm{NaCl}$ slurry (see T. Wang et al., 2016 and Tham et al., 2016 for details). The average sensitivity of $\mathrm{N}_{2} \mathrm{O}_{5}$ and $\mathrm{ClNO}_{2}$ was $0.9 \pm 0.3$ and $0.7 \pm 0.2 \mathrm{~Hz} \mathrm{pptv}^{-1}$, respectively. The dependence of the sensitivity on the relative humidity was measured during the field study (see Fig. S1) and was used to correct for the RH effect based on the measured ambient $\mathrm{RH}$ values. The detection limits of $\mathrm{N}_{2} \mathrm{O}_{5}$ and $\mathrm{ClNO}_{2}$ were both 6 pptv ( $2 \sigma, 1$ min-averaged data).

The inlet of the CIMS instrument was set approximately $1.5 \mathrm{~m}$ above the roof with $6 \mathrm{~m}$ long PFA-Teflon tubing as the sampling line. The total sampling flow was set as 11 stan- dard liters per minute (SLPM). Four SLPM were diverted into the CIMS, the $\mathrm{O}_{3}$ analyzer, and $\mathrm{NO}_{x}$ analyzer, and the remaining part was evacuated directly from the system. The total residence time was less than $1 \mathrm{~s}$ in the sampling system. Following our previous practice, the inlet tubing and fittings were replaced every afternoon and washed in an ultrasonic bath to reduce the influence of particle deposition on the tubing wall. The loss of $\mathrm{N}_{2} \mathrm{O}_{5}$ on the tubing wall was checked on site by injecting $\mathrm{N}_{2} \mathrm{O}_{5}$ into the ambient air before and after the tubing replacement; the loss was found to be around $10 \%$ in the "clean" tubing and nearly $40 \%$ by the next afternoon. Because our analysis mainly focused on data from the first few hours of evening, the loss was insignificant and thus was not corrected in our final data. However, this bias could be important in the later period before tube replacement. The uncertainty of the measurement was estimated to be $\pm 25 \%$ for both $\mathrm{N}_{2} \mathrm{O}_{5}$ and $\mathrm{ClNO}_{2}$ (T. Wang et al., 2016). The time resolution for the measurement was approximately $10 \mathrm{~s}$, and the derived data were later averaged to a time resolution of $1 \mathrm{~min}$ for further analysis.

\subsection{Other measurements}

Trace gases of $\mathrm{CO}, \mathrm{SO}_{2}, \mathrm{O}_{3}, \mathrm{NO}_{x}$, total reactive nitrogen $\left(\mathrm{NO}_{y}\right)$, nitrous acid (HONO), C2 to C10 non-methane hydrocarbons (NMHCs), oxygenated hydrocarbons (OVOCs), and aerosol chemical composition and number concentrations were also measured. Table 1 summarizes the principle, detection limit and uncertainty of the measuring instruments.

$\mathrm{CO}$ was observed using a gas filter correlation analyzer (Thermo Scientific, Model 48i). $\mathrm{SO}_{2}$ was measured using a pulsed fluorescence analyzer (Thermo Scientific, Model 43i). $\mathrm{O}_{3}$ was determined using a UV photometric analyzer (Thermo Scientific, Model 49i). $\mathrm{NO}$ and $\mathrm{NO}_{2}$ were detected with a chemiluminescence instrument (Thermo Sci- 
Table 1. Technique, limit of detection, and uncertainty of measuring instruments for trace gases and aerosols.

\begin{tabular}{|c|c|c|c|}
\hline Species & Measurement techniques & Uncertainty & Detection limits \\
\hline $\mathrm{ClNO}_{2}, \mathrm{~N}_{2} \mathrm{O}_{5}$ & CIMS & $\pm 25 \%$ & $6 \mathrm{pptv}$ \\
\hline HONO & LOPAP & $\pm 20 \%$ & $7 \mathrm{pptv}$ \\
\hline $\mathrm{O}_{3}$ & UV photometry & $\pm 5 \%$ & $0.5 \mathrm{ppbv}$ \\
\hline NO & Chemiluminescence & $\pm 20 \%$ & $0.06 \mathrm{ppbv}$ \\
\hline $\mathrm{NO}_{2}$ & $\begin{array}{l}\text { Photolytical converter and } \\
\text { chemiluminescence }\end{array}$ & $\pm 20 \%$ & $0.3 \mathrm{ppbv}$ \\
\hline $\mathrm{NO}_{y}$ & $\begin{array}{l}\text { MoO catalytic converter and } \\
\text { chemiluminescence }\end{array}$ & $\pm 5 \%$ & $<0.1 \mathrm{ppbv}$ \\
\hline $\mathrm{SO}_{2}$ & Pulsed-UV fluorescence & $\pm 5 \%$ & $0.1 \mathrm{ppbv}$ \\
\hline $\mathrm{CO}$ & IR photometry & $\pm 5 \%$ & 4 ppbv \\
\hline NMHCs & GC-FID/MS & $\pm 15 \%-20 \%$ & $20-300 \mathrm{pptv}$ \\
\hline OVOCs & DNPH-HPLC & $\pm 1 \%-15 \%$ & $20-450 \mathrm{pptv}$ \\
\hline $\mathrm{PM}_{2.5}$ & MAAP & $\pm 10 \%$ & $<0.1 \mu \mathrm{g} \mathrm{m}^{-3}$ \\
\hline Aerosol ions & GAC-IC & $\pm 10 \%$ & $0.01-0.16 \mu \mathrm{g} \mathrm{m}^{-3}$ \\
\hline $\mathrm{OC} / \mathrm{EC}$ & RT-4 SUNSET & $\pm 4 \%-6 \%$ & $0.2 \mu \mathrm{g} \mathrm{cm}^{-2}$ \\
\hline
\end{tabular}

entific, Model 42i) with a photolytic converter to convert $\mathrm{NO}_{2}$ to $\mathrm{NO}$ (Xu et al., 2013). $\mathrm{NO}_{y}$ was determined using a chemiluminescence analyzer which was equipped with a molybdenum oxide (MoO) catalytic converter (Thermo Scientific, Model 42i-Y). HONO was detected using a long path absorption photometer (QUMA, Model LOPAP-03) (Xu et al., 2015). NMHCs were determined using an online gas chromatograph (GC) coupled with a flame ionization detector (FID) and a mass spectrometer (MS) (Wang et al., 2014). NMHCs were only measured from 2 to 8 January 2017 due to the maintenance of the GCMS after 8 January. OVOCs (e.g., formaldehyde, acetaldehyde, acetone, and methyl ethyl ketone) were sampled using 2,4dinitrophenylhydrazine (DNPH) cartridges every $3 \mathrm{~h}$ and were later analyzed with a high-performance liquid chromatography (HPLC) system (Cui et al., 2016).

Concentrations of $\mathrm{PM}_{2.5}$ were detected with a multi-angle absorption photometer (MAAP; Thermo Scientific, Model 5012). The ionic compositions of $\mathrm{PM}_{2.5}$ were measured with an ion chromatography (GAC-IC) system equipped with a gas and aerosol collector at a time resolution of $30 \mathrm{~min}$ (Dong et al., 2012), and the data were also averaged every $1 \mathrm{~h}$ to meet the time resolution of other components of $\mathrm{PM}_{2.5}$. Organic carbon (OC) and elemental carbon (EC) were measured using an online OC/EC analyzer (RT-4, SUNSET) with a time resolution of $1 \mathrm{~h}$ (Bauer et al., 2009). A scanning mobility particle sizer (SMPS Model 3936L75, TSI) was used to determine the dry-state particle number size distribution, covering the size range from 16.5 to $1000 \mathrm{~nm}$. The ambient (wet) particle number size distributions were estimated based on a size-resolved kappa-Köhler function considering the variation with relative humidity (Hennig et al., 2005; Liu et al., 2014). In the present study, data with a RH greater than $90 \%$ were excluded due to the large uncertainty of the growth factor at very high RH. The aerosol surface area density was then derived using the ambient particle number size distribution (wet) and an assumption of spherical particles with an estimated uncertainty of around $30 \%$ (Tham et al., 2016; Z. Wang et al., 2017).

Meteorological parameters were measured with a portable weather station (WXT520, Vaisala, Finland), including temperature, relative humidity $(\mathrm{RH})$, wind direction, wind speed, and pressure. A pyranometer (CMP22, Kipp \& Zonen B.V., Holland) was used to measure the solar radiation, and the data were then utilized to derive the photolysis frequency of $\mathrm{NO}_{2}$ based on the method of Trebs et al. (2009).

\subsection{Chemical box model}

To estimate the daytime formation of nitric acid via the reaction of $\mathrm{OH}+\mathrm{NO}_{2}$, an observation-based chemical box model developed with the latest version of the MCM (v3.3.1) (Jenkin et al., 2003, 2015; Saunders et al., 2003) and an updated chlorine $(\mathrm{Cl})$ radical chemistry module (Xue et al., 2015) was utilized to estimate the mixing ratio of $\mathrm{OH}$ radicals and the reaction rate of $\mathrm{OH}+\mathrm{NO}_{2}$. The integrated production of nitric acid during daytime was then calculated based on the simulation results. The box model was constrained with the observation data every $10 \mathrm{~min}$, including the data relating to $\mathrm{N}_{2} \mathrm{O}_{5}, \mathrm{ClNO}_{2}, \mathrm{HONO}, \mathrm{O}_{3}, \mathrm{NO}, \mathrm{NO}_{2}, \mathrm{SO}_{2}$, $\mathrm{CO}, \mathrm{C} 2$ to $\mathrm{C} 10$ NMHCs, OVOCs (formaldehyde, acetaldehyde, acetone, and MEK), temperature, aerosol surface area density, and $J\left(\mathrm{NO}_{2}\right)$, which were first averaged or interpolated. Average concentrations of NMHC species during the day (07:00 to 17:00) and at night (17:00 to 07:00 of the next day) are shown in Table S1. A function considering the variation of the solar zenith angle (Saunders et al., 2003) was used to calculate the photolysis frequencies of $\mathrm{HONO}, \mathrm{O}_{3}$, and other species in clear sky, which were then corrected with the $J\left(\mathrm{NO}_{2}\right)$ values in the real environment. The $J\left(\mathrm{ClNO}_{2}\right)$ 
was treated the same as in Tham et al. (2016). The lifetime of unconstrained species with respect to the physical loss was set as $8 \mathrm{~h}$ in a boundary layer with a depth of $1000 \mathrm{~m}$ (equivalent to $3.47 \times 10^{-5} \mathrm{~s}^{-1}$ ) in order to avoid their accumulation. The model was run from 00:00 on 3 January to 11:00 on 8 January 2017. To stabilize the intermediate species, the simulation for the first $24 \mathrm{~h}$ was repeated six times. Sensitivity tests were carried out by reducing the input concentrations by $10 \%$ to check the deviation of the average daytime (07:00-17:00) rate of the $\mathrm{OH}+\mathrm{NO}_{2}$ reaction. The simulated rate of the $\mathrm{OH}+\mathrm{NO}_{2}$ reaction was most sensitive to HONO, followed by $\mathrm{NO}_{x}$ and OVOCs (see Sect. S1 and Fig. S2 in the Supplement).

\section{Results and discussion}

\subsection{Overview of the observation}

Figure 2 shows the time series of $\mathrm{N}_{2} \mathrm{O}_{5}, \mathrm{ClNO}_{2}$, components of $\mathrm{PM}_{2.5}$, and related trace gases and meteorological parameters from 18:40 on 2 January to 11:00 on 15 January 2017. The average temperature and $\mathrm{RH}$ values during the measurement period were $17 \pm 4^{\circ} \mathrm{C}$ and $86 \pm 14 \%$, respectively. A severe pollution episode occurred from 3 to 7 January due to stagnant meteorological conditions (Fig. 3a), and the concentrations of most pollutants decreased to very low levels on 9 January and from 12 to 15 January, which corresponded to the change in weather conditions. The most polluted days were 5 and 6 January with the highest $\mathrm{PM}_{2.5}$ value of $400 \mu \mathrm{g} \mathrm{m}^{-3}$ and the highest $\mathrm{O}_{3}$ concentration of $160 \mathrm{ppbv}$. The $\mathrm{PM}_{2.5}$ data from the PRD regional air quality monitoring network revealed that the HGS site was within the most polluted area during this haze event (Fig. 3b). This pollution event was characterized by concurrent high levels of $\mathrm{PM}_{2.5}$ and $\mathrm{O}_{3}$ and was in contrast to the winter haze in north China, which experienced high $\mathrm{PM}_{2.5}$ values but low $\mathrm{O}_{3}$ concentrations (e.g., Sun et al., 2016; H. Wang et al., 2018a). The mixing ratios of $\mathrm{N}_{2} \mathrm{O}_{5}$ and $\mathrm{ClNO}_{2}$ were up to 3358 and 8324 pptv (1 min time resolution), respectively, indicating active $\mathrm{N}_{2} \mathrm{O}_{5}$ heterogeneous chemistry.

Very high concentrations of aerosol nitrate (up to $108 \mu \mathrm{g} \mathrm{m}^{-3} ; 1 \mathrm{~h}$ time resolution) were also observed during the multi-day episode. Nitrate contributed to $24 \%$ of the total $\mathrm{PM}_{2.5}$ mass concentration on average, which was comparable to that of organic matter $(\mathrm{OM}=1.7 \cdot \mathrm{OC}, 28 \%)$ and much higher than that of sulfate $(16 \%)$ and ammonium $(11 \%)$. The contribution of nitrate to the $\mathrm{PM}_{2.5}$ increased with an increase in the nitrate concentration, and reached nearly $40 \%$ at its peak, indicating that nitrate was a dominant component of the $\mathrm{PM}_{2.5}$ on the most polluted days. The concentration of $\mathrm{NO}_{3}^{-}$exhibited a concurrent increase with that of $\mathrm{CINO}_{2}$ in the early nighttime from 3 to 4,4 to 5,5 to 6 , and 9 to 10 January (see Fig. 4), suggesting that $\mathrm{N}_{2} \mathrm{O}_{5}$ heterogeneous reactions significantly contributed to the formation of nitrate during the night. The measured increases of the $\mathrm{NO}_{3}^{-}$ concentration during these four nights were 17.1, 50.9, 43.3, and $32.7 \mu \mathrm{g} \mathrm{m}^{-3}$, respectively. A similar increase in $\mathrm{ClNO}_{2}$ was observed from 6 to 7 January, but the composition of the $\mathrm{PM}_{2.5}$ was not available due to instrument maintenance. Apart from chemical reactions, the evolution of the planetary boundary layer (PBL) also affects the concentrations of trace gas and aerosols. The height of PBL generally decreases after sunset due to the fast decrease in the land temperature, which can lead to the accumulation of primary pollutants (and secondary pollutants) at the surface if significant local sources are present. For example, on the night from 4 to 5 January (see Fig. 5), the $\mathrm{CO}$ and $\mathrm{NO}_{y}$ levels increased between 18:00 and 19:00 LT with the enhancement of $\mathrm{ClNO}_{2}$ and nitrate, indicative of an accumulation of primary emissions; however, after this period of time the primary pollutants decreased for $3 \mathrm{~h}$ while $\mathrm{ClNO}_{2}$ and nitrate continued to increase due to the nighttime chemical process.

In the remainder of this paper, we will focus on the detailed analysis of the abovementioned five nights to investigate the role of $\mathrm{N}_{2} \mathrm{O}_{5}$ heterogeneous chemistry in nitrate formation.

\section{2 $\mathrm{N}_{2} \mathrm{O}_{5}$ heterogeneous chemistry on the selected nights}

\subsubsection{Production of $\mathrm{NO}_{3}$ and $\mathrm{N}_{2} \mathrm{O}_{5}$}

The first step in the nighttime nitrate formation via $\mathrm{N}_{2} \mathrm{O}_{5}$ chemistry is the production of $\mathrm{NO}_{3}$ and $\mathrm{N}_{2} \mathrm{O}_{5}$. To gain insight into the key factors affecting the $\mathrm{NO}_{3} / \mathrm{N}_{2} \mathrm{O}_{5}$ chemistry, the variation of $\mathrm{N}_{2} \mathrm{O}_{5}$ and the production rate of $\mathrm{NO}_{3}$ were examined in relation to some relevant gases and meteorological parameters on the selected five nights. Figure 5 shows the data for the night from 4 to 5 January as an example. Some common features were identified for all five nights. In general, low wind speed $\left(<2.0 \mathrm{~m} \mathrm{~s}^{-1}\right)$ at night facilitated the accumulation of air pollutants, and high $\mathrm{RH}$ was favorable for $\mathrm{N}_{2} \mathrm{O}_{5}$ heterogeneous uptake. In addition, high aerosol surface area density provided interfaces for $\mathrm{N}_{2} \mathrm{O}_{5}$ heterogeneous reactions.

In the first couple of hours after sunset (Fig. 5, red rectangle), $\mathrm{N}_{2} \mathrm{O}_{5}$ exhibited a peak and then quickly dropped to hundreds of pptv, while nitrate and $\mathrm{ClNO}_{2}$ concurrently increased, which was indicative of the local production and loss of $\mathrm{N}_{2} \mathrm{O}_{5}$. NO was below the detection limit during this period. The production rates of $\mathrm{NO}_{3}\left(P_{\mathrm{NO}_{3}}=\right.$ $\left.k_{\mathrm{NO}_{2}+\mathrm{O}_{3}}\left[\mathrm{NO}_{2}\right]\left[\mathrm{O}_{3}\right]\right)$ were the fastest just after sunset and decreased gradually due to reduced $\mathrm{O}_{3}$ levels. There was a period later in the night (22:00 to 01:00) when fresh emissions of $\mathrm{NO}$ were observed, and the production of $\mathrm{NO}_{3}$ was suppressed due to the titration of $\mathrm{O}_{3}$ by NO. In the later nighttime, NO was below the detection limit (Fig. 5, blue rectangle). During this period, $\mathrm{NO}_{3}$ and $\mathrm{N}_{2} \mathrm{O}_{5}$ were produced at moderate rates, and the very low $\mathrm{N}_{2} \mathrm{O}_{5}$ concentrations (below the detection limit) suggested a fast loss of $\mathrm{N}_{2} \mathrm{O}_{5}$ prob- 


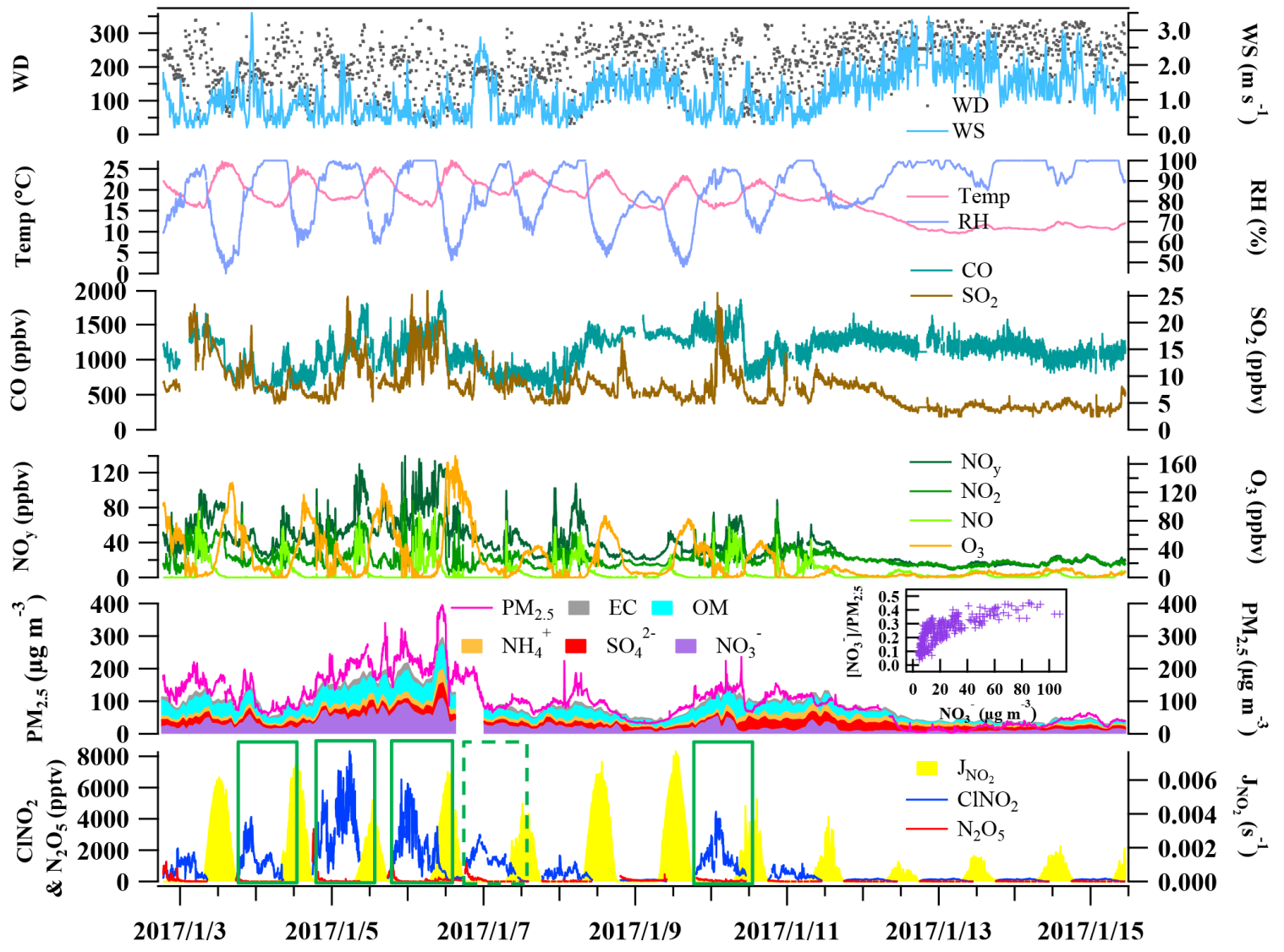

Figure 2. Time series of $\mathrm{N}_{2} \mathrm{O}_{5}, \mathrm{ClNO}_{2}$, components of $\mathrm{PM}_{2.5}$, and related trace gases and meteorological parameters from 18:40 on 2 January to 11:00 on 15 January 2017. The inset figure shows the variation of the ratio of nitrate to $\mathrm{PM}_{2.5}$ with an increasing nitrate concentration. The green rectangles in the figure indicate the five days used for detailed analysis.
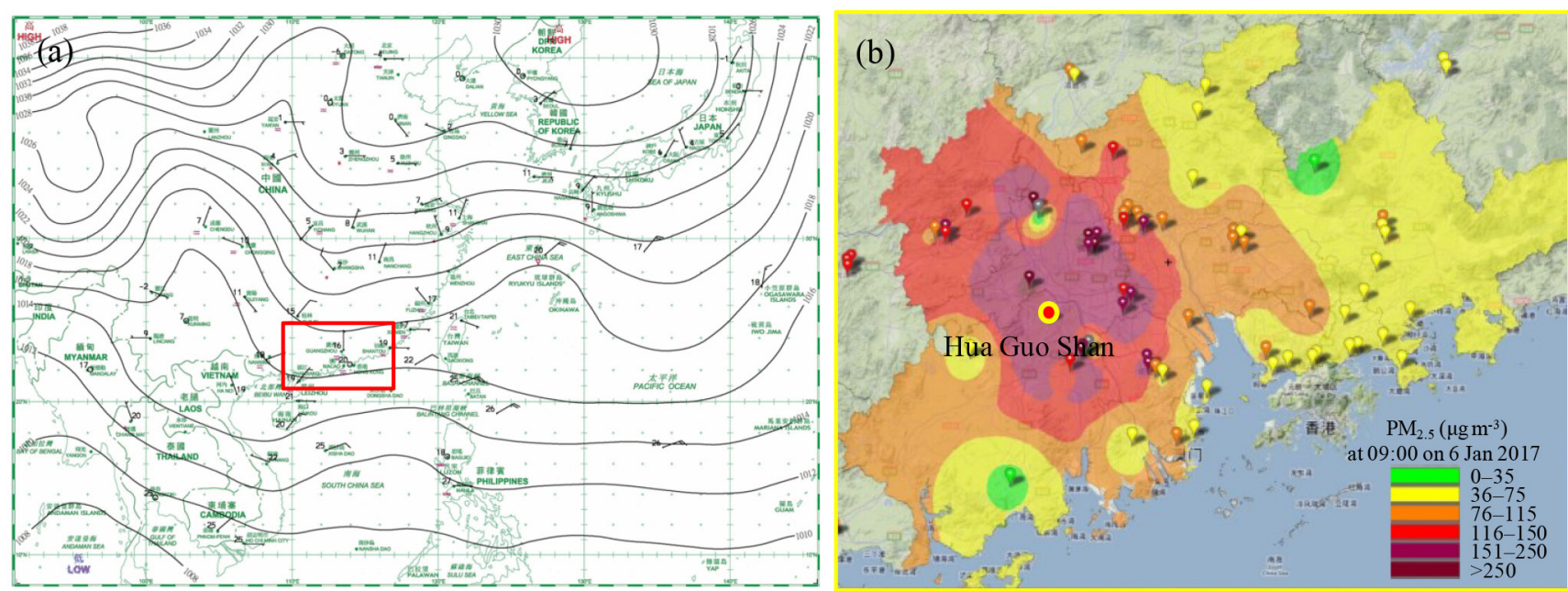

Figure 3. (a) Surface weather chart at 08:00 LT on 6 January 2017, downloaded from the Hong Kong Observatory website, indicating stagnant conditions. (b) The distribution of $\mathrm{PM}_{2.5}$ concentrations in the PRD region at 09:00 LT on 6 January 2017. This figure was captured from the following website: http://113.108.142.147:20031/GDPublish/publish.aspx (last access: 17 November 2018). 

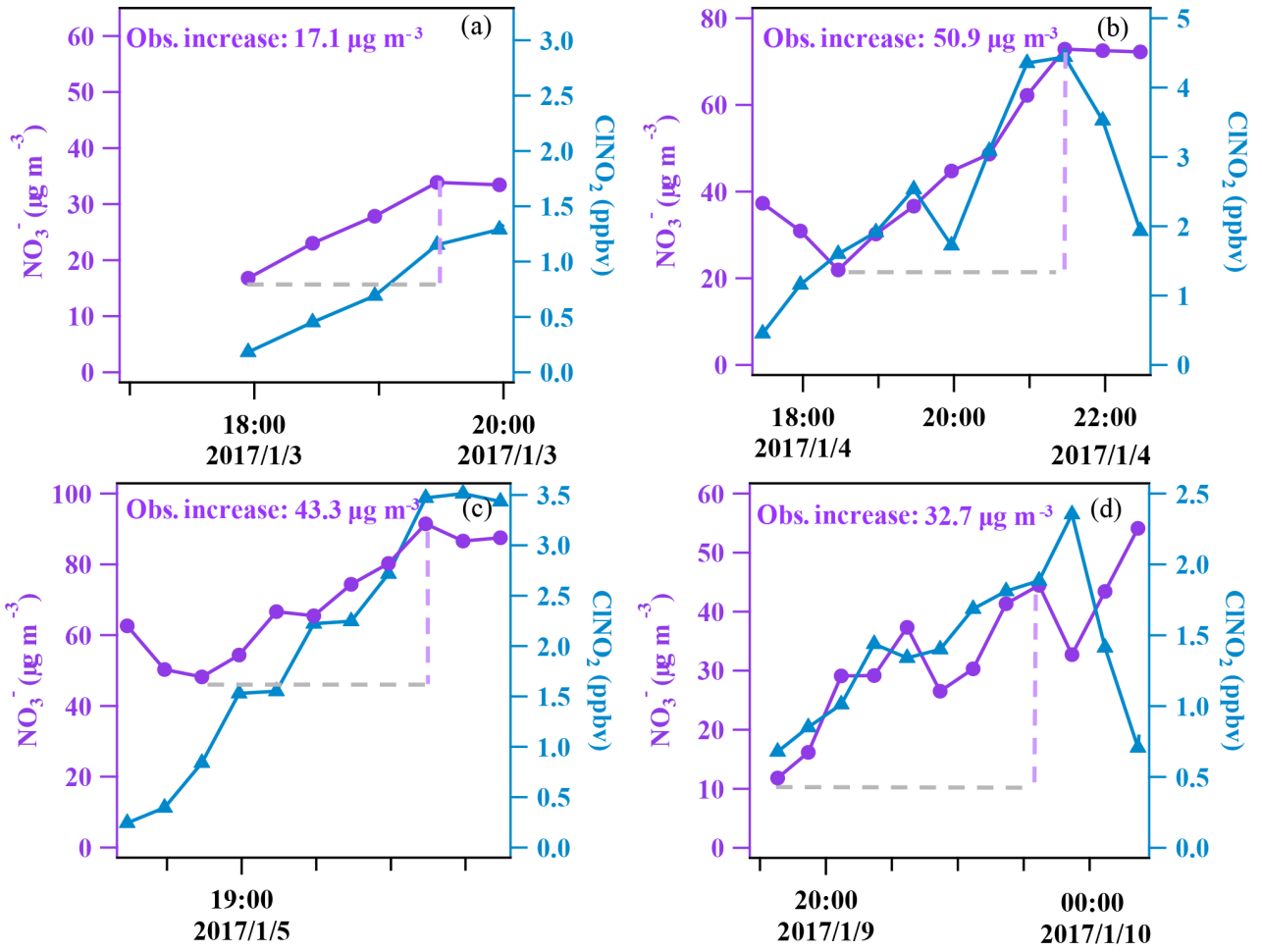

Figure 4. The covariance of aerosol nitrate and $\mathrm{ClNO}_{2}$ in the early nighttime (at a 30 min time resolution) for four nights.

ably leading to the local production of $\mathrm{ClNO}_{2}$ and nitrate, which was not revealed in the observed variations of $\mathrm{ClNO}_{2}$ and nitrate. The concentrations of $\mathrm{ClNO}_{2}$ and nitrate during this period fluctuated due to the change in the air masses indicated by the change in $\mathrm{SO}_{2}$ concentrations and wind speeds.

\subsubsection{The $\mathrm{N}_{2} \mathrm{O}_{5}$ uptake coefficient and $\mathrm{ClNO}_{2}$ yield}

The $\mathrm{N}_{2} \mathrm{O}_{5}$ uptake coefficient and $\mathrm{ClNO}_{2}$ yield, in combination with the reactivity of $\mathrm{NO}_{3}$ with $\mathrm{NO}$ and VOCs, determines the loss pathways of $\mathrm{NO}_{3}$ and $\mathrm{N}_{2} \mathrm{O}_{5}$. To derive the uptake coefficient of $\mathrm{N}_{2} \mathrm{O}_{5}$, a method suggested by McLaren et al. (2010) was applied which treated $\mathrm{NO}_{3}$ and $\mathrm{N}_{2} \mathrm{O}_{5}$ as a whole $\left(\left[\mathrm{NO}_{3}\right]+\left[\mathrm{N}_{2} \mathrm{O}_{5}\right]\right)$ without assuming that the chemical system was in a steady state. This approach considers that the change of $\mathrm{NO}_{3}$ and $\mathrm{N}_{2} \mathrm{O}_{5}$ concentrations is mainly due to $\mathrm{NO}_{3} / \mathrm{N}_{2} \mathrm{O}_{5}$ chemistry; thus, it requires that the air mass has relatively stable chemical conditions and is not subject to fresh $\mathrm{NO}$ emissions. It also requires that $\mathrm{ClNO}_{2}$ is produced from the $\mathrm{N}_{2} \mathrm{O}_{5}$ chemistry and has an increasing trend to derive the yield of $\mathrm{ClNO}_{2}$. This method is applicable for the early nighttime (Fig. 5, red rectangle; Sect. 3.2.1) for these five nights.
The variation rate of $\left[\mathrm{NO}_{3}\right]+\left[\mathrm{N}_{2} \mathrm{O}_{5}\right]$ can be calculated by deducting the production rate of $\left[\mathrm{NO}_{3}\right]+\left[\mathrm{N}_{2} \mathrm{O}_{5}\right]$ with its loss rate as follows:

$\frac{\mathrm{d}\left(\left[\mathrm{N}_{2} \mathrm{O}_{5}\right]+\left[\mathrm{NO}_{3}\right]\right)}{\mathrm{d} t}=P_{\mathrm{NO}_{3}}-L_{\mathrm{N}_{2} \mathrm{O}_{5}+\mathrm{NO}_{3}}$

The loss of $\left[\mathrm{NO}_{3}\right]+\left[\mathrm{N}_{2} \mathrm{O}_{5}\right]$ is via the reaction of $\mathrm{NO}_{3}$ with VOCs and $\mathrm{N}_{2} \mathrm{O}_{5}$ heterogeneous reactions, which can both be expressed as pseudo-first-order losses:

$$
\begin{aligned}
L_{\mathrm{N}_{2} \mathrm{O}_{5}+\mathrm{NO}_{3}} & =L_{\mathrm{NO}_{3}}+L_{\mathrm{N}_{2} \mathrm{O}_{5}} \\
& =k^{\prime} \mathrm{NO}_{3}\left[\mathrm{NO}_{3}\right]+k_{\mathrm{N}_{2} \mathrm{O}_{5}}^{\prime}\left[\mathrm{N}_{2} \mathrm{O}_{5}\right],
\end{aligned}
$$

where $k_{\mathrm{NO}_{3}}^{\prime}$ and $k_{\mathrm{N}_{2} \mathrm{O}_{5}}^{\prime}$ represent the total first-order rate constants for $\mathrm{NO}_{3}$ and $\mathrm{N}_{2} \mathrm{O}_{5}$, respectively. The loss rate of $\mathrm{N}_{2} \mathrm{O}_{5}$ can then be obtained from Eq. (3):

$$
\begin{aligned}
L_{\mathrm{N}_{2} \mathrm{O}_{5}} & =k_{\mathrm{N}_{2} \mathrm{O}_{5}}^{\prime}\left[\mathrm{N}_{2} \mathrm{O}_{5}\right]=k_{\mathrm{NO}_{2}+\mathrm{O}_{3}}\left[\mathrm{NO}_{2}\right]\left[\mathrm{O}_{3}\right] \\
& -\frac{\mathrm{d}\left[\mathrm{N}_{2} \mathrm{O}_{5}\right]}{\mathrm{d} t}-\frac{\mathrm{d}\left[\mathrm{NO}_{3}\right]}{\mathrm{d} t}-k_{\mathrm{NO}_{3}}^{\prime}\left[\mathrm{NO}_{3}\right]
\end{aligned}
$$

Because $\mathrm{NO}_{3}$ was not measured, it was calculated by assuming an equilibrium of $\mathrm{NO}_{2}-\mathrm{NO}_{3}-\mathrm{N}_{2} \mathrm{O}_{5}$ as shown in Eq. (4). High levels of NO would break this equilibrium. Thus, the periods with detected NO were excluded. 
Table 2. Average $\mathrm{N}_{2} \mathrm{O}_{5}$ concentration values, $\mathrm{N}_{2} \mathrm{O}_{5}$ uptake coefficients, $\mathrm{ClNO}_{2}$ yields, and other related parameters and maximum $\mathrm{ClNO}$ concentration values in the early nighttime for the five selected nights.

\begin{tabular}{|c|c|c|c|c|c|c|c|c|c|c|c|c|c|}
\hline Date/time & $\begin{array}{l}\mathrm{N}_{2} \mathrm{O}_{5} \\
\text { (pptv) }\end{array}$ & $\begin{array}{r}\mathrm{Max} \mathrm{ClNO}_{2} \\
\text { (pptv) }\end{array}$ & $\begin{array}{r}\mathrm{NO}_{2} \\
\text { (ppbv) }\end{array}$ & $\begin{array}{r}\mathrm{O}_{3} \\
\text { (ppbv) }\end{array}$ & $\begin{array}{l}\mathrm{RH} \\
(\%)\end{array}$ & $\begin{array}{r}\mathrm{Sa} \\
\left(\mu \mathrm{m}^{2} \mathrm{~cm}^{-3}\right)\end{array}$ & $\begin{array}{r}P_{\mathrm{NO}_{3}} \\
\left(\text { ppbvh }^{-1}\right)\end{array}$ & $\begin{array}{r}k_{\mathrm{NO}_{3}}^{\prime} \\
\left(10^{-3} \mathrm{~s}^{-1}\right)\end{array}$ & $\begin{array}{r}L_{\mathrm{N}_{2} \mathrm{O}_{5}} \\
\left(\mathrm{ppbvh}^{-1}\right)\end{array}$ & $\begin{array}{r}k_{\mathrm{NO}_{3}}^{\prime} /\left(\mathrm{Keq}\left[\mathrm{NO}_{2}\right]\right) \\
\left(10^{-5} \mathrm{~s}^{-1}\right)\end{array}$ & $\begin{array}{r}k_{\mathrm{N}_{2} \mathrm{O}_{5}}^{\prime} \\
\left(10^{-3} \mathrm{~s}^{-1}\right)\end{array}$ & $\gamma \mathrm{N}_{2} \mathrm{O}_{5}$ & $\phi_{\mathrm{ClNO}_{2}}$ \\
\hline 3 January $17: 40-19: 00$ & 200 & 1029 & 20 & 78 & 59 & 2170 & 4.3 & 0.516 & 4.3 & 3.03 & 8.81 & 0.066 & 0.18 \\
\hline 4 January $17: 00-22: 00$ & 700 & 4608 & 24 & 61 & 82 & 6452 & 3.3 & 1.54 & 3.2 & 6.07 & 4.16 & 0.009 & 0.32 \\
\hline 5 January $17: 00-22: 00$ & 338 & 4828 & 18 & 73 & 81 & 8399 & 3.4 & 0.790 & 3.3 & 4.06 & 9.00 & 0.015 & 0.29 \\
\hline 6 January $17: 00-22: 40$ & 326 & 2908 & 13 & 82 & 77 & 5092 & 2.8 & 0.677 & 2.6 & 4.95 & 3.78 & 0.013 & 0.20 \\
\hline 9 January 19:00-00:20 & 121 & 2553 & 19 & 41 & 85 & 5173 & 1.9 & 0.516 & 1.9 & 1.40 & 4.28 & 0.015 & 0.28 \\
\hline
\end{tabular}

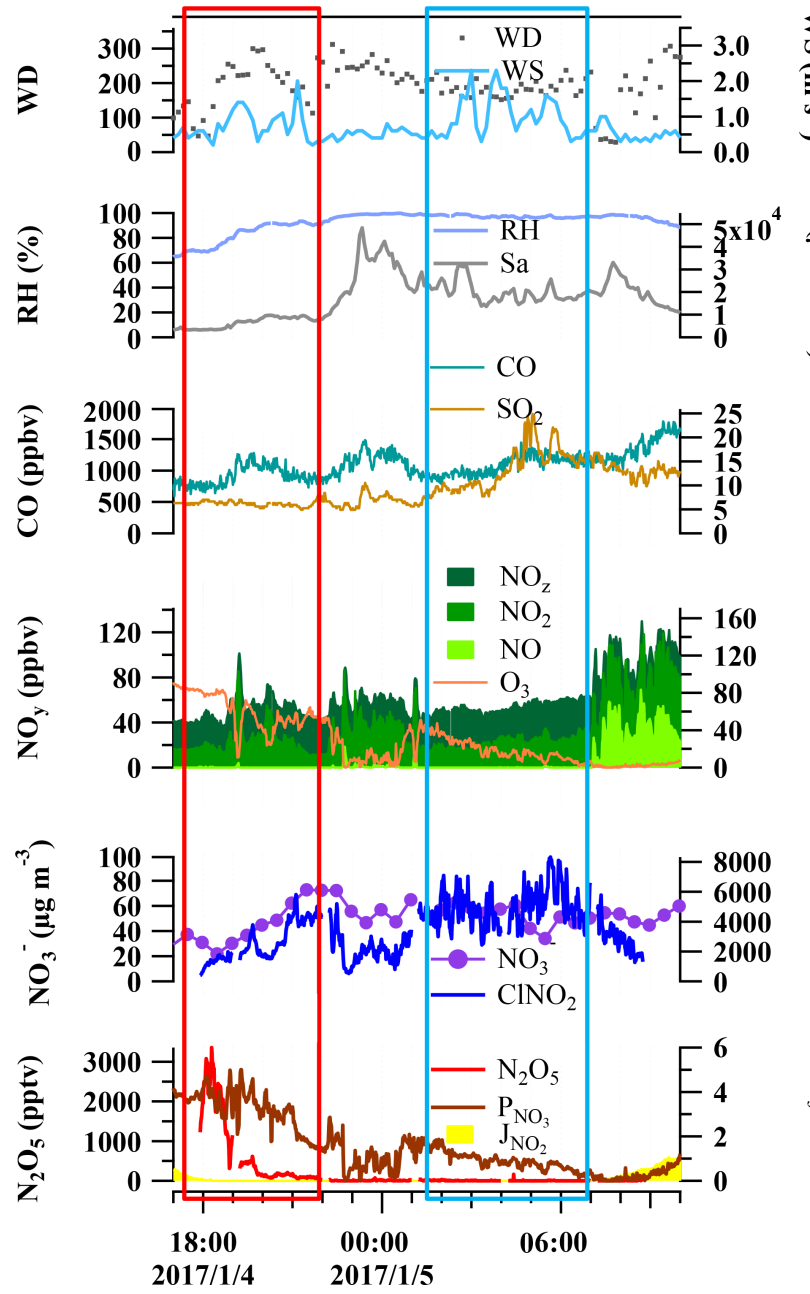

Figure 5. Variation of $\mathrm{N}_{2} \mathrm{O}_{5}, \mathrm{ClNO}_{2}, \mathrm{NO}_{3}^{-}$, and trace gases and meteorological conditions during the night from 4 to 5 January 2017 as an example from the five selected nights.

$\mathrm{d}\left[\mathrm{NO}_{3}\right] / \mathrm{d} t$ and $\mathrm{d}\left[\mathrm{N}_{2} \mathrm{O}_{5}\right] / \mathrm{d} t$ were calculated as the rate of change of $\mathrm{NO}_{3}$ and $\mathrm{N}_{2} \mathrm{O}_{5}$, respectively, at a time resolution of 10 min. $k_{\mathrm{NO}_{3}}^{\prime}$ was derived using the measured concentrations of NMHCs as in Eq. (5) by interpolating the data of the NMHCs to a 10 min time resolution. The $\mathrm{NO}_{3}$ reactivity with VOCs $\left(k_{\mathrm{NO} 3}^{\prime}\right)$ in the early nighttime ranged from 0.516 to $1.54 \times 10^{-3} \mathrm{~s}^{-1}$ (Table 2), which was higher than those derived at Mt. TMS in winter $2013\left(0.17\right.$ to $\left.1.1 \times 10^{-3} \mathrm{~s}^{-1}\right)$
(Brown et al., 2016), but lower than those in the North China Plain during the summertime ( 2 to $57 \times 10^{-3} \mathrm{~s}^{-1}$ ) (Tham et al., 2016; H. Wang et al., 2017, 2018b; Z. Wang et al., 2017). NMHCs were not measured from 9 to 10 January 2017. We used the average $k_{\mathrm{NO}_{3}}^{\prime}$ in the early nighttime from 3 to 4 January as a replacement because these two periods had similar pollution levels for most pollutants. For the later nighttime (Fig. 5, blue rectangle), low levels of $\mathrm{N}_{2} \mathrm{O}_{5}$ and moderate levels of $P_{\mathrm{NO}_{3}}$ made Eq. (3) inapplicable even though $\mathrm{NO}$ was not detected.

$\begin{aligned} {\left[\mathrm{NO}_{3}\right] } & =\frac{\left[\mathrm{N}_{2} \mathrm{O}_{5}\right]}{\left[\mathrm{NO}_{2}\right] \cdot K_{\mathrm{eq}}} \\ k^{\prime}{ }_{\mathrm{NO}_{3}} & =\sum k_{i}\left[\mathrm{VOC}_{i}\right]\end{aligned}$

Finally, the uptake coefficient of $\mathrm{N}_{2} \mathrm{O}_{5}$ was derived using Eq. (6) for every $10 \mathrm{~min}$ and averaged for each selected period. In Eq. (6), $C_{\mathrm{N}_{2} \mathrm{O}_{5}}$ is the mean molecular speed of $\mathrm{N}_{2} \mathrm{O}_{5}$, and $S_{\mathrm{a}}$ is the aerosol surface area density. The yield of $\mathrm{ClNO}_{2}$ was derived via dividing the integrated production of $\mathrm{ClNO}_{2}$ $\left(\left[\mathrm{ClNO}_{2}\right]_{\max }\right.$ ) by the integrated loss of $\mathrm{N}_{2} \mathrm{O}_{5}$ since sunset as Eq. (7).

$k^{\prime}{ }_{\mathrm{N}_{2} \mathrm{O}_{5}}=\frac{L_{\mathrm{N}_{2} \mathrm{O}_{5}}}{\left[\mathrm{~N}_{2} \mathrm{O}_{5}\right]}=\frac{1}{4} C_{\mathrm{N}_{2} \mathrm{O}_{5}} S_{\mathrm{a}} \gamma_{\mathrm{N}_{2} \mathrm{O}_{5}}$

$\phi=\frac{\left[\mathrm{ClNO}_{2}\right]_{\max }}{\int L_{\mathrm{N}_{2} \mathrm{O}_{5}} \mathrm{~d} t}$

The relative importance of the $\mathrm{NO}_{3}$ reactions with VOCs and $\mathrm{N}_{2} \mathrm{O}_{5}$ heterogeneous reactions can be examined by comparing the values of the loss coefficient of the $\mathrm{NO}_{3}$ reactions $\left(\frac{k^{\prime} \mathrm{NO}_{3}}{\left[\mathrm{NO}_{2}\right] \cdot K_{\text {eq }}}\right)$ and $\mathrm{N}_{2} \mathrm{O}_{5}$ heterogeneous reactions $\left(k_{\mathrm{N}_{2} \mathrm{O}_{5}}^{\prime}\right)$ (Tham et al., 2016). Based on the calculations, the values of $\frac{k^{\prime} \mathrm{NO}_{3}}{\left[\mathrm{NO}_{2}\right] \cdot K_{\text {eq }}}$ were $1.40 \times 10^{-5}$ to $6.07 \times 10^{-5} \mathrm{~s}^{-1}$ (see Table 2), while those of $k_{\mathrm{N}_{2} \mathrm{O}_{5}}^{\prime}$ were $3.78 \times 10^{-3}$ to $9.00 \times 10^{-3} \mathrm{~s}^{-1}$, which was 2 orders of magnitude higher than $\frac{k^{\prime} \mathrm{NO}_{3}}{\left[\mathrm{NO}_{2}\right] \cdot K_{\text {eq }}}$, suggesting that $\mathrm{N}_{2} \mathrm{O}_{5}$ heterogeneous reactions were the dominant loss pathway for both $\mathrm{NO}_{3}$ and $\mathrm{N}_{2} \mathrm{O}_{5}$.

The average $\gamma_{\mathrm{N}_{2} \mathrm{O}_{5}}$ and $\phi_{\mathrm{ClNO}_{2}}$ derived for the early night in the five cases are listed in Table 2. The data show that the uptake coefficient ranged from 0.009 to 0.066 , which was comparable with previous values derived at Mt. Tai Mo Shan (TMS) in Hong Kong (0.004 to 0.022) (Brown et al., 2016) 
Table 3. Average values of the $\mathrm{N}_{2} \mathrm{O}_{5}$ loss rate and related parameters for selected periods in the later nighttime.

\begin{tabular}{lrrrrr}
\hline Date/time & $\begin{array}{r}\mathrm{NO}_{2} \\
(\mathrm{ppbv})\end{array}$ & $\begin{array}{r}\mathrm{O}_{3} \\
(\mathrm{ppbv})\end{array}$ & $\begin{array}{r}\mathrm{P}_{\mathrm{NO}_{3}} \\
\left(\mathrm{ppbv} \mathrm{h}^{-1}\right)\end{array}$ & $\begin{array}{r}\mathrm{k}^{\prime} \mathrm{NO}_{3} \\
\left(10^{-3} \mathrm{~s}^{-1}\right)\end{array}$ & $\begin{array}{r}\mathrm{L}_{\mathrm{N}_{2} \mathrm{O}_{5}} \\
\left(\mathrm{ppbv}^{-1}\right)\end{array}$ \\
\hline 3-4 January 21:00-05:00 & 20.8 & 20.7 & 1.00 & 0.684 & 1.00 \\
5 January 01:30-06:50 & 22.4 & 19.5 & 0.96 & 1.45 & 0.96 \\
5-6 January 23:40-01:10 & 21.1 & 25.5 & 1.26 & 1.13 & 1.26 \\
6-7 January 23:00-06:00 & 22.1 & 14.4 & 0.82 & 0.709 & 0.82 \\
10 January 01:50-03:30 & 24.8 & 15.6 & 0.90 & - & 0.90 \\
\hline
\end{tabular}

and in the North China Plain (0.006 to 0.102) (Tham et al., 2016, 2018; H. Wang et al., 2017, 2018b; X. Wang et al., 2017; Z. Wang et al., 2017; Zhou et al., 2018). It is interesting to see a much higher $\gamma_{\mathrm{N}_{2} \mathrm{O}_{5}}$ value (0.066) on 3 January than those on other four nights $(0.009-0.015)$, which resulted from higher $P_{\mathrm{NO}_{3}}$ but much lower Sa and relatively low $\mathrm{N}_{2} \mathrm{O}_{5}$ concentrations on 3 January. We examined known factors affecting the loss of $\mathrm{NO}_{3}$ and $\mathrm{N}_{2} \mathrm{O}_{5}$ such as the concentrations of NO, NMHCs, and aerosol compositions, but found no obvious difference between 3 January and the other nights. The yield in this study varied from 0.18 to 0.32 , which was similar to most studies in China (Tham et al., 2016, 2018; Z. Wang et al., 2017; Yun et al., 2018; Zhou et al., 2018).

The uncertainty of the above $\gamma_{\mathrm{N}_{2} \mathrm{O}_{5}}$ was estimated to be $\pm 45 \%$ due to the measurement uncertainty of $\mathrm{N}_{2} \mathrm{O}_{5}$ $( \pm 25 \%), \mathrm{NO}_{2}( \pm 20 \%), \mathrm{O}_{3}( \pm 5 \%)$, and $\mathrm{Sa}( \pm 30 \%)$. The uncertainty of $\phi_{\mathrm{ClNO}_{2}}$ was mainly caused by the uncertainty of $\mathrm{NO}_{2}( \pm 20 \%), \mathrm{O}_{3}( \pm 5 \%)$, and $\mathrm{ClNO}_{2}( \pm 25 \%)$ and was estimated to be $\pm 30 \%$. The correlation between $\gamma_{\mathrm{N}_{2} \mathrm{O}_{5}}$, $\phi_{\mathrm{ClNO}_{2}}$, and the concentrations of aerosol compositions (see Table S2) or RH was investigated, and the results (not shown here) did not indicate any significant dependence of $\gamma_{\mathrm{N}_{2} \mathrm{O}_{5}}$ or $\phi_{\mathrm{ClNO}_{2}}$ on these parameters.

\subsection{Nitrate formation potential $p\left(\mathrm{NO}_{3}^{-}\right)$through $\mathrm{N}_{2} \mathrm{O}_{5}$ chemistry}

\subsubsection{Nighttime $p\left(\mathrm{NO}_{3}^{-}\right)$}

The formation potential of $\mathrm{NO}_{3}^{-}$through $\mathrm{N}_{2} \mathrm{O}_{5}$ chemistry is the total amount of $\mathrm{NO}_{3}^{-}$accumulated from $\mathrm{N}_{2} \mathrm{O}_{5}$ heterogeneous loss. It can be calculated by deducting the integrated production of $\mathrm{CINO}_{2}$ from the integrated loss of $\mathrm{N}_{2} \mathrm{O}_{5}$ as follows:

$$
\begin{aligned}
p\left(\mathrm{NO}_{3}^{-}\right) & =(2-\phi) \int L_{\mathrm{N}_{2} \mathrm{O}_{5}} \mathrm{~d} t \\
& =2 \int L_{\mathrm{N}_{2} \mathrm{O}_{5}} \mathrm{~d} t-\left[\mathrm{ClNO}_{2}\right]_{\max }
\end{aligned}
$$

In the early nighttime, the average loss rate of $\mathrm{N}_{2} \mathrm{O}_{5}$ $\left(L_{\mathrm{N}_{2} \mathrm{O}_{5}}\right)$ ranged from 1.9 to $4.3 \mathrm{ppbvh}^{-1}$ (Table 2 ), which was close to the average $P_{\mathrm{NO}_{3}}$ due to the dominance of the $\mathrm{N}_{2} \mathrm{O}_{5}$ heterogeneous reactions in $\mathrm{NO}_{3}$ and $\mathrm{N}_{2} \mathrm{O}_{5}$ loss. Based

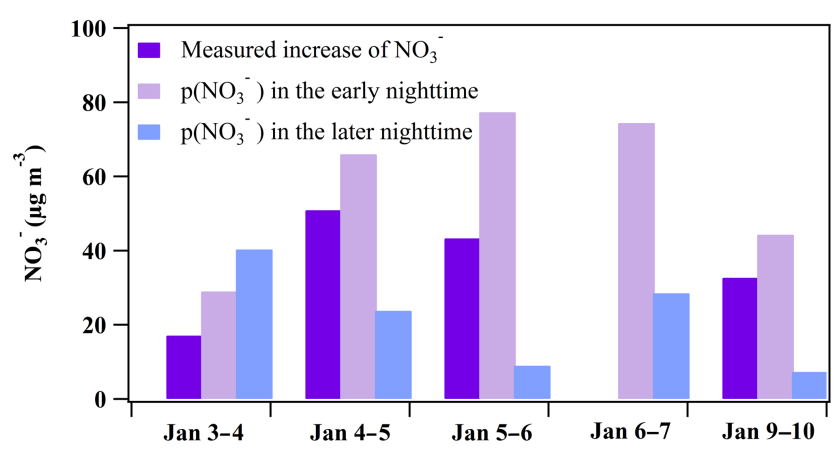

Figure 6. Comparison between the measured $\mathrm{NO}_{3}^{-}$increase and the $\mathrm{NO}_{3}^{-}$formation potential in the early nighttime (periods in Table 2: 3 January 17:40-19:00, 4 January 17:00-22:00, 5 January 17:00-22:00, 6 January 17:00-22:40, and 9 January 19:00-00:20) and in the later nighttime (periods in Table 3: 3-4 January 21:0005:00, 5 January 01:30-06:50, 5-6 January 23:40-01:10, 6-7 January 23:00-06:00, and 10 January 01:50-03:30).

on the derived $\mathrm{N}_{2} \mathrm{O}_{5}$ loss rate and the maximum $\mathrm{ClNO}_{2}$ concentration, the formation potential of $\mathrm{NO}_{3}^{-}$was derived and ranged from 29.0 to $77.3 \mu \mathrm{g} \mathrm{m}^{-3}$ as shown in Fig. 6. The measured increase of the $\mathrm{NO}_{3}^{-}$concentration in the early nighttime can be completely explained by the integrated production of $\mathrm{NO}_{3}^{-}$via the $\mathrm{N}_{2} \mathrm{O}_{5}$ heterogeneous reactions during the same period.

In the later nighttime, the method described in Sect. 3.2.2 was not valid for calculating the $\mathrm{N}_{2} \mathrm{O}_{5}$ heterogeneous loss rate as mentioned above. We attempted to estimate the formation potential of nitrate by assuming that the $\mathrm{N}_{2} \mathrm{O}_{5}$ heterogeneous reactions continued to dominate the loss of $\mathrm{NO}_{3}+$ $\mathrm{N}_{2} \mathrm{O}_{5}$ in the later nighttime. The $k_{\mathrm{NO}_{3}}^{\prime}$ values in the later nighttime were comparable to those in the early nighttime, and the high $\mathrm{RH}$ (close to $100 \%$ ) in the later nighttime was favorable for $\mathrm{N}_{2} \mathrm{O}_{5}$ heterogeneous reactions. We assumed that all $\mathrm{NO}_{3}$ was quickly consumed by the $\mathrm{N}_{2} \mathrm{O}_{5}$ heterogeneous reactions, which means that the loss rate of $\mathrm{N}_{2} \mathrm{O}_{5}$ approximated to the production rate of $\mathrm{NO}_{3}\left(L_{\mathrm{N}_{2} \mathrm{O}_{5}} \approx P_{\mathrm{NO}_{3}}\right)$. As listed in Table 3 , the $\mathrm{N}_{2} \mathrm{O}_{5}$ loss rates ranged from 0.82 to $1.26 \mathrm{ppbv} \mathrm{h}^{-1}$, which were significantly lower than those derived in the early nighttime. The derived $\mathrm{N}_{2} \mathrm{O}_{5}$ loss rate here and the yield of $\mathrm{ClNO}_{2}$ in the early nighttime were used to es- 


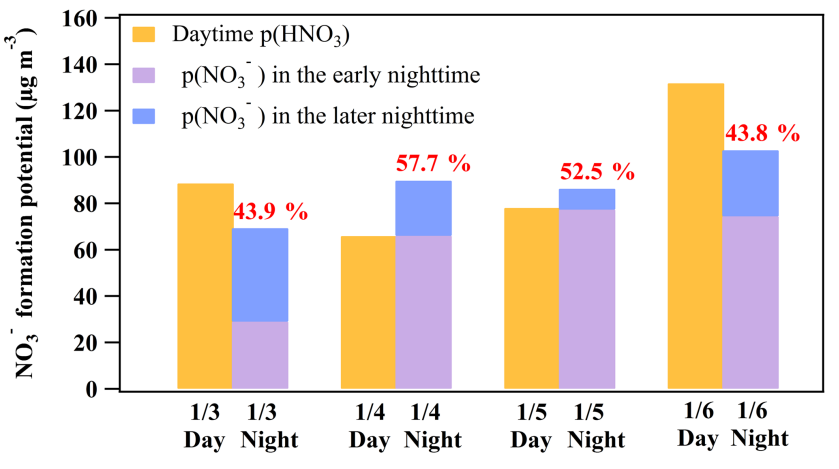

Figure 7. Comparison between the daytime (07:00 to 17:00 LT; assuming that all gas-phase $\mathrm{HNO}_{3}$ is partitioned into particle phase) and nighttime (17:00 to 07:00 LT of the next day) $\mathrm{NO}_{3}^{-}$formation potential. The early nighttime of each day represents the periods in Table 2, including 3 January 17:40-19:00, 4 January 17:0022:00, 5 January 17:00-22:00, 6 January 17:00-22:40, and 9 January 19:00-00:20. The later nighttime of each day represents the periods in Table 3, including 3-4 January 21:00-05:00, 5 January 01:30-06:50, 5-6 January 23:40-01:10, 6-7 January 23:00-06:00, and 10 January 01:50-03:30. The intercomparison of the $\mathrm{NO}_{3}^{-}$formation potential during the day and night on 9 and 10 January was not conducted due to the lack of NMHC data after 8 January which made the model simulation of $\mathrm{OH}$ infeasible during the day on 9 January.

timate the formation potential of $\mathrm{NO}_{3}^{-}$in the later nighttime. As shown in Fig. 6, the nitrate produced during these later periods ranged from 7.3 to $40.3 \mu \mathrm{g} \mathrm{m}^{-3}$, which was lower than values in the early nighttime for four nights, indicating that the nighttime nitrate from $\mathrm{N}_{2} \mathrm{O}_{5}$ chemistry was mainly produced in the early nighttime.

\subsubsection{Comparison with the daytime production of $\mathrm{HNO}_{3}$}

During the daytime, the formation of $\mathrm{NO}_{3}^{-}$is mainly from the gas-particle partitioning of the gas-phase $\mathrm{HNO}_{3}$ formed via the $\mathrm{OH}+\mathrm{NO}_{2}$ reaction. Hence, the daytime formation potential of $\mathrm{HNO}_{3}\left(p\left(\mathrm{HNO}_{3}\right)\right)$ can be treated as the upper limit for the locally produced daytime aerosol nitrate. To calculate the daytime $p\left(\mathrm{HNO}_{3}\right)$, a box model based on MCM v3.3.1 was used to derive the mixing ratio of $\mathrm{OH}$ and the rates of $\mathrm{OH}+\mathrm{NO}_{2}$ as described in Sect. 2.4. This model was previously used in our study at Wangdu in northern China (Tham et al., 2016). The calculated mixing ratios of $\mathrm{OH}$ at Wangdu with this model compared well with those observed by the laser-induced fluorescence (LIF) technique (Tan et al., 2017). In the present study, the average daytime $\mathrm{OH}$ (07:00 to $17: 00$ ) mixing ratios were 1.71 to $3.82 \times 10^{6} \mathrm{molec} \mathrm{cm}^{-3}$ from 3 to 7 January, as listed in Table 4, with the maximum values reaching 3.24 to $6.71 \times 10^{6}$ molec $\mathrm{cm}^{-3}$. The detailed results for $\mathrm{OH}$ can be found in Fig. S3.
Table 4. Average $\mathrm{OH}$ mixing ratio and rate of $\mathrm{OH}+\mathrm{NO}_{2}$ during the daytime (07:00 to 17:00 LT) from 3 to 7 January 2017.

\begin{tabular}{lrrr}
\hline Date & $\begin{array}{r}\mathrm{OH} \\
\left(\mathrm{molec} \mathrm{cm}^{-3}\right)\end{array}$ & $\begin{array}{r}\mathrm{NO}_{2} \\
(\mathrm{ppbv})\end{array}$ & $\begin{array}{r}\mathrm{OH}+\mathrm{NO}_{2} \\
\left(\mathrm{ppbv} \mathrm{h}^{-1}\right)\end{array}$ \\
\hline 3 January & $2.18 \times 10^{6}$ & 36.2 & 3.49 \\
4 January & $2.47 \times 10^{6}$ & 23.6 & 2.60 \\
5 January & $2.62 \times 10^{6}$ & 30.8 & 3.09 \\
6 January & $3.82 \times 10^{6}$ & 31.5 & 5.21 \\
7 January & $1.71 \times 10^{6}$ & 18.4 & 1.40 \\
\hline
\end{tabular}

The average production rates of $\mathrm{HNO}_{3}$ via the $\mathrm{OH}+\mathrm{NO}_{2}$ reaction were 1.40 to $5.21 \mathrm{ppbv} \mathrm{h}^{-1}$ from 3 to 7 January, and the integrated formation potential of $\mathrm{HNO}_{3}$ during the daytime was 35.7 to $131.8 \mu \mathrm{g} \mathrm{m}^{-3}$, which was comparable to the nighttime $p\left(\mathrm{NO}_{3}^{-}\right)$that ranged from 69.3 to $102.9 \mu \mathrm{g} \mathrm{m}^{-3}$ (Fig. 7). The nighttime production of nitrate via the heterogeneous uptake of $\mathrm{N}_{2} \mathrm{O}_{5}$ accounted for $43.8 \%$ to $57.7 \%$ of the total nitrate $\left(\mathrm{NO}_{3}^{-}+\mathrm{HNO}_{3}\right)$ produced in a $24 \mathrm{~h}$ period at the site. These results underscored the important role of $\mathrm{N}_{2} \mathrm{O}_{5}$ heterogeneous chemistry in nitrate formation in this severe winter haze in southern China.

\section{Concluding remarks}

With the use of concurrent measurements of nitrate, $\mathrm{ClNO}_{2}$, and related pollutants, this study demonstrates the important contribution of $\mathrm{N}_{2} \mathrm{O}_{5}$ heterogeneous uptake in nitrate formation. Current chemical transport models have difficulties simulating this nitrate production pathway. Therefore, more research efforts are needed to improve the representations of $\gamma_{\mathrm{N}_{2} \mathrm{O}_{5}}$ and $\phi_{\mathrm{ClNO}_{2}}$ for the better prediction of nitrate in the models. The observation-based approach presented here can be applied to investigate nitrate formation in other areas.

Data availability. The data used in this study are available upon request from Tao Wang (cetwang@polyu.edu.hk) and Dingli Yue (dingliyue@163.com).

Supplement. The supplement related to this article is available online at: https://doi.org/10.5194/acp-18-17515-2018-supplement.

Author contributions. TW designed the research. WW conducted the CIMS measurements, and YZ, DY, HY, MX, CY, and PS performed the measurements of the other parameters used in this study. HY, TW, MX, and WW analyzed the data. HY and TW wrote the paper, and all authors contributed to discussion and commented on the paper. 
Competing interests. The authors declare that they have no conflict of interest.

Special issue statement. This article is part of the special issue "Multiphase chemistry of secondary aerosol formation under severe haze". It is not associated with a conference.

Acknowledgements. The authors thank Qinyi Li and Xiao Fu for helpful discussions, Yaru Wang and Yiheng Liang for their help with analyzing the OVOC and aerosol composition, and Naiwen Zhang for her help with the HONO measurements. This study was supported by the Research Grants Council of Hong Kong (HK-RGC; C5022-14G and PolyU 153026/14P) and the National Natural Science Foundation (NNSF) of China (91544213). Zhe Wang acknowledges the support of the NNSF of China (41505103) and HK-RGC (25221215).

Edited by: Jingkun Jiang

Reviewed by: three anonymous referees

\section{References}

Anttila, T., Kiendler-Scharr, A., Tillmann, R., and Mentel, T. F.: On the reactive uptake of gaseous compounds by organic-coated aqueous aerosols: Theoretical analysis and application to the heterogeneous hydrolysis of $\mathrm{N}_{2} \mathrm{O}_{5}$, J. Phys. Chem. A, 110, 1043510443, 2006.

Bauer, J. J., Yu, X.-Y., Cary, R., Laulainen, N., and Berkowitz, C.: Characterization of the sunset semi-continuous carbon aerosol analyzer, J. Air Waste Manage., 59, 826-833, 2009.

Bertram, T. H. and Thornton, J. A.: Toward a general parameterization of $\mathrm{N}_{2} \mathrm{O}_{5}$ reactivity on aqueous particles: the competing effects of particle liquid water, nitrate and chloride, Atmos. Chem. Phys., 9, 8351-8363, https://doi.org/10.5194/acp-9-8351-2009, 2009.

Brown, S. S. and Stutz, J.: Nighttime radical observations and chemistry, Chem. Soc. Rev., 41, 6405-6447, 2012.

Brown, S. S., Dubé, W. P., Tham, Y. J., Zha, Q., Xue, L., Poon, S., Wang, Z., Blake, D. R., Tsui, W., and Parrish, D. D.: Nighttime Chemistry at a High Altitude Site Above Hong Kong, J. Geophys. Res.-Atmos., 121, 2457-2475, https://doi.org/10.1002/2015JD024566, 2016.

Chang, W. L., Bhave, P. V., Brown, S. S., Riemer, N., Stutz, J., and Dabdub, D.: Heterogeneous Atmospheric Chemistry, Ambient Measurements, and Model Calculations of $\mathrm{N}_{2} \mathrm{O}_{5}$ : A Review, Aerosol Sci. Tech., 45, 665-695, https://doi.org/10.1080/02786826.2010.551672, 2011.

Cui, L., Zhang, Z., Huang, Y., Lee, S. C., Blake, D. R., Ho, K. F., Wang, B., Gao, Y., Wang, X. M., and Louie, P. K. K.: Measuring OVOCs and VOCs by PTR-MS in an urban roadside microenvironment of Hong Kong: relative humidity and temperature dependence, and field intercomparisons, Atmos. Meas. Tech., 9, 5763-5779, https://doi.org/10.5194/amt-9-5763-2016, 2016.

Davis, J. M., Bhave, P. V., and Foley, K. M.: Parameterization of $\mathrm{N} 2 \mathrm{O} 5$ reaction probabilities on the surface of particles containing ammonium, sulfate, and nitrate, Atmos. Chem. Phys., 8, 52955311, https://doi.org/10.5194/acp-8-5295-2008, 2008.

Dentener, F. J. and Crutzen, P. J.: Reaction of $\mathrm{N}_{2} \mathrm{O}_{5}$ on tropospheric aerosols: Impact on the global distributions of $\mathrm{NO}_{x}, \mathrm{O}_{3}$, and $\mathrm{OH}$, J. Geophys. Res.-Atmos., 98, 7149-7163, 1993.

Dong, H.-B., Zeng, L.-M., Hu, M., Wu, Y.-S., Zhang, Y.-H., Slanina, J., Zheng, M., Wang, Z.-F., and Jansen, R.: Technical Note: The application of an improved gas and aerosol collector for ambient air pollutants in China, Atmos. Chem. Phys., 12, 1051910533, https://doi.org/10.5194/acp-12-10519-2012, 2012.

Evans, M. J. and Jacob, D. J.: Impact of new laboratory studies of $\mathrm{N}_{2} \mathrm{O}_{5}$ hydrolysis on global model budgets of tropospheric nitrogen oxides, ozone, and OH, Geophys. Res. Lett., 32, L09813, https://doi.org/10.1029/2005GL022469, 2005.

Finlayson-Pitts, B. J., Ezell, M. J., and Pitts, J. N.: Formation of chemically active chlorine compounds by reactions of atmospheric $\mathrm{NaCl}$ particles with gaseous $\mathrm{N}_{2} \mathrm{O}_{5}$ and $\mathrm{ClONO}_{2}$, Nature, 337, 241-244, 1989.

Fu, X., Wang, X., Guo, H., Cheung, K., Ding, X., Zhao, X., He, Q., Gao, B., Zhang, Z., and Liu, T.: Trends of ambient fine particles and major chemical components in the Pearl River Delta region: observation at a regional background site in fall and winter, Sci. Total Environ., 497, 274-281, 2014.

Ge, X., He, Y., Sun, Y., Xu, J., Wang, J., Shen, Y., and Chen, M.: Characteristics and formation mechanisms of fine particulate nitrate in typical urban areas in China, Atmosphere, 8, 62, https://doi.org/10.3390/atmos8030062, 2017.

Geng, G., Zhang, Q., Tong, D., Li, M., Zheng, Y., Wang, S., and $\mathrm{He}, \mathrm{K}$.: Chemical composition of ambient $\mathrm{PM}_{2.5}$ over China and relationship to precursor emissions during 2005-2012, Atmos. Chem. Phys., 17, 9187-9203, https://doi.org/10.5194/acp17-9187-2017, 2017.

Hennig, T., Massling, A., Brechtel, F., and Wiedensohler, A.: A tandem DMA for highly temperature-stabilized hygroscopic particle growth measurements between $90 \%$ and $98 \%$ relative humidity, J. Aerosol Sci., 36, 1210-1223, 2005.

Huang, R. J., Zhang, Y. L., Bozzetti, C., Ho, K. F., Cao, J. J., Han, Y. M., Daellenbach, K. R., Slowik, J. G., Platt, S. M., Canonaco, F., Zotter, P., Wolf, R., Pieber, S. M., Bruns, E. A., Crippa, M., Ciarelli, G., Piazzalunga, A., Schwikowski, M., Abbaszade, G., Schnelle-Kreis, J., Zimmermann, R., An, Z. S., Szidat, S., Baltensperger, U., El Haddad, I., and Prevot, A. S. H.: High secondary aerosol contribution to particulate pollution during haze events in China, Nature, 514, 218-222, https://doi.org/10.1038/Nature13774, 2014.

Jenkin, M. E., Saunders, S. M., Wagner, V., and Pilling, M. J.: Protocol for the development of the Master Chemical Mechanism, MCM v3 (Part B): tropospheric degradation of aromatic volatile organic compounds, Atmos. Chem. Phys., 3, 181-193, https://doi.org/10.5194/acp-3-181-2003, 2003.

Jenkin, M. E., Young, J. C., and Rickard, A. R.: The MCM v3.3.1 degradation scheme for isoprene, Atmos. Chem. Phys., 15, 11433-11459, https://doi.org/10.5194/acp-15-11433-2015, 2015.

Li, H., Zhang, Q., Zheng, B., Chen, C., Wu, N., Guo, H., Zhang, Y., Zheng, Y., Li, X., and He, K.: Nitrate-driven urban haze pollution during summertime over the North China Plain, Atmos. Chem. Phys., 18, 5293-5306, https://doi.org/10.5194/acp18-5293-2018, 2018. 
Liu, H. J., Zhao, C. S., Nekat, B., Ma, N., Wiedensohler, A., van Pinxteren, D., Spindler, G., Müller, K., and Herrmann, H.: Aerosol hygroscopicity derived from size-segregated chemical composition and its parameterization in the North China Plain, Atmos. Chem. Phys., 14, 2525-2539, https://doi.org/10.5194/acp-14-2525-2014, 2014.

Li, W., Liu, X., Zhang, Y., Sun, K., Wu, Y., Xue, R., Zeng, L., Qu, Y., and An, J.: Characteristics and formation mechanism of regional haze episodes in the Pearl River Delta of China, J. Environ. Sci., 63, 236-249, 2017.

Liu, X., Sun, K., Qu, Y., Hu, M., Sun, Y., Zhang, F., and Zhang, Y.: Secondary formation of sulfate and nitrate during a haze episode in megacity Beijing, China, Aerosol Air Qual. Res., 15, 22462257, 2015.

Makar, P., Wiebe, H., Staebler, R., Li, S., and Anlauf, K.: Measurement and modeling of particle nitrate formation, J. Geophys. Res.-Atmos., 103, 13095-13110, 1998.

McDuffie, E. E., Fibiger, D. L., Dubé, W. P., Lopez-Hilfiker, F., Lee, B. H., Thornton, J. A., Shah, V., Jaeglé, L., Guo, H., and Weber, R. J.: Heterogeneous $\mathrm{N}_{2} \mathrm{O}_{5}$ uptake during winter: Aircraft measurements during the 2015 WINTER campaign and critical evaluation of current parameterizations, J. Geophys. Res.-Atmos., 123, 4345-4372, https://doi.org/10.1002/2018JD028336, 2018.

McLaren, R., Wojtal, P., Majonis, D., McCourt, J., Halla, J. D., and Brook, J.: $\mathrm{NO}_{3}$ radical measurements in a polluted marine environment: links to ozone formation, Atmos. Chem. Phys., 10, 4187-4206, https://doi.org/10.5194/acp-10-4187-2010, 2010.

Munger, J. W., Fan, S. M., Bakwin, P. S., Goulden, M. L., Goldstein, A., Colman, A. S., and Wofsy, S. C.: Regional budgets for nitrogen oxides from continental sources: Variations of rates for oxidation and deposition with season and distance from source regions, J. Geophys. Res.-Atmos., 103, 8355-8368, 1998.

Pathak, R. K., Wu, W. S., and Wang, T.: Summertime $\mathrm{PM}_{2.5}$ ionic species in four major cities of China: nitrate formation in an ammonia-deficient atmosphere, Atmos. Chem. Phys., 9, 17111722, https://doi.org/10.5194/acp-9-1711-2009, 2009.

Pathak, R. K., Wang, T., and Wu, W. S.: Nighttime enhancement of $\mathrm{PM}_{2.5}$ nitrate in ammonia-poor atmospheric conditions in Beijing and Shanghai: Plausible contributions of heterogeneous hydrolysis of $\mathrm{N}_{2} \mathrm{O}_{5}$ and $\mathrm{HNO}_{3}$ partitioning, Atmos. Environ., 45, 1183-1191, https://doi.org/10.1016/j.atmosenv.2010.09.003, 2011.

Phillips, G. J., Thieser, J., Tang, M., Sobanski, N., Schuster, G., Fachinger, J., Drewnick, F., Borrmann, S., Bingemer, H., Lelieveld, J., and Crowley, J. N.: Estimating $\mathrm{N}_{2} \mathrm{O}_{5}$ uptake coefficients using ambient measurements of $\mathrm{NO}_{3}, \mathrm{~N}_{2} \mathrm{O}_{5}, \mathrm{ClNO}_{2}$ and particle-phase nitrate, Atmos. Chem. Phys., 16, 13231-13249, https://doi.org/10.5194/acp-16-13231-2016, 2016.

Qu, Z., Henze, D. K., Capps, S. L., Wang, Y., Xu, X., Wang, J., and Keller, M.: Monthly top-down $\mathrm{NO}_{x}$ emissions for China (20052012): A hybrid inversion method and trend analysis, J. Geophys. Res.-Atmos., 122, 4600-4625, 2017.

Reuter, M., Buchwitz, M., Hilboll, A., Richter, A., Schneising, O., Hilker, M., Heymann, J., Bovensmann, H., and Burrows, J.: Decreasing emissions of $\mathrm{NO}_{x}$ relative to $\mathrm{CO}_{2}$ in East Asia inferred from satellite observations, Nat. Geosci., 7, 792-795, https://doi.org/10.1038/NGEO2257, 2014.

Riemer, N., Vogel, H., Vogel, B., Schell, B., Ackermann, I., Kessler, C., and Hass, H.: Impact of the heterogeneous hydrolysis of
$\mathrm{N}_{2} \mathrm{O}_{5}$ on chemistry and nitrate aerosol formation in the lower troposphere under photosmog conditions, J. Geophys. Res., 108, 4144, https://doi.org/10.1029/2002JD002436, 2003.

Riemer, N., Vogel, H., Vogel, B., Anttila, T., Kiendler, Scharr, A., and Mentel, T.: Relative importance of organic coatings for the heterogeneous hydrolysis of $\mathrm{N}_{2} \mathrm{O}_{5}$ during summer in Europe, J. Geophys. Res., 114, D17307, https://doi.org/10.1029/2008JD011369, 2009.

Roberts, J. M., Osthoff, H. D., Brown, S. S., Ravishankara, A., Coffman, D., Quinn, P., and Bates, T.: Laboratory studies of products of $\mathrm{N}_{2} \mathrm{O}_{5}$ uptake on Cl-containing substrates, Geophys. Res. Lett., 36, L20808, https://doi.org/10.1029/2009GL040448, 2009.

Saunders, S. M., Jenkin, M. E., Derwent, R. G., and Pilling, M. J.: Protocol for the development of the Master Chemical Mechanism, MCM v3 (Part A): tropospheric degradation of nonaromatic volatile organic compounds, Atmos. Chem. Phys., 3, 161-180, https://doi.org/10.5194/acp-3-161-2003, 2003.

Schaap, M., van Loon, M., ten Brink, H. M., Dentener, F. J., and Builtjes, P. J. H.: Secondary inorganic aerosol simulations for Europe with special attention to nitrate, Atmos. Chem. Phys., 4, 857-874, https://doi.org/10.5194/acp-4-857-2004, 2004.

Seinfeld, J. H. and Pandis, S. N.: Atmospheric chemistry and physics: from air pollution to climate change, John Wiley \& Sons, New York, 2016.

Sun, Y., Chen, C., Zhang, Y., Xu, W., Zhou, L., Cheng, X., Zheng, H., Ji, D., Li, J., and Tang, X.: Rapid formation and evolution of an extreme haze episode in Northern China during winter 2015, Sci. Rep., 6, 27151, https://doi.org/10.1038/srep27151, 2016.

Tan, Z., Fuchs, H., Lu, K., Hofzumahaus, A., Bohn, B., Broch, S., Dong, H., Gomm, S., Häseler, R., He, L., Holland, F., Li, X., Liu, Y., Lu, S., Rohrer, F., Shao, M., Wang, B., Wang, M., Wu, Y., Zeng, L., Zhang, Y., Wahner, A., and Zhang, Y.: Radical chemistry at a rural site (Wangdu) in the North China Plain: observation and model calculations of $\mathrm{OH}, \mathrm{HO}_{2}$ and $\mathrm{RO}_{2}$ radicals, Atmos. Chem. Phys., 17, 663-690, https://doi.org/10.5194/acp17-663-2017, 2017.

Tham, Y. J., Wang, Z., Li, Q., Yun, H., Wang, W., Wang, X., Xue, L., Lu, K., Ma, N., Bohn, B., Li, X., Kecorius, S., Größ, J., Shao, M., Wiedensohler, A., Zhang, Y., and Wang, T.: Significant concentrations of nitryl chloride sustained in the morning: investigations of the causes and impacts on ozone production in a polluted region of northern China, Atmos. Chem. Phys., 16, 14959-14977, https://doi.org/10.5194/acp-16-14959-2016, 2016.

Tham, Y. J., Wang, Z., Li, Q., Wang, W., Wang, X., Lu, K., Ma, N., Yan, C., Kecorius, S., Wiedensohler, A., Zhang, Y., and Wang, T.: Heterogeneous $\mathrm{N}_{2} \mathrm{O}_{5}$ uptake coefficient and production yield of $\mathrm{ClNO}_{2}$ in polluted northern China: roles of aerosol water content and chemical composition, Atmos. Chem. Phys., 18, 1315513171, https://doi.org/10.5194/acp-18-13155-2018, 2018.

Trebs, I., Bohn, B., Ammann, C., Rummel, U., Blumthaler, M., Königstedt, R., Meixner, F. X., Fan, S., and Andreae, M. O.: Relationship between the $\mathrm{NO}_{2}$ photolysis frequency and the solar global irradiance, Atmos. Meas. Tech., 2, 725-739, https://doi.org/10.5194/amt-2-725-2009, 2009.

Wang, H., Lu, K., Chen, X., Zhu, Q., Chen, Q., Guo, S., Jiang, M., Li, X., Shang, D., Tan, Z., Wu, Y., Wu, Z., Zou, Q., Zheng, Y., Zeng, L., Zhu, T., Hu, M., and Zhang, Y.: High $\mathrm{N}_{2} \mathrm{O}_{5}$ Concentrations Observed in Urban Beijing: Implications of a Large Ni- 
trate Formation Pathway, Environ. Sci. Tech. Lett., 4, 416-420, https://doi.org/10.1021/acs.estlett.7b00341, 2017.

Wang, H., Lu, K., Chen, X., Zhu, Q., Wu, Z., Wu, Y., and Sun, K.: Fast particulate nitrate formation via $\mathrm{N}_{2} \mathrm{O}_{5}$ uptake aloft in winter in Beijing, Atmos. Chem. Phys., 18, 10483-10495, https://doi.org/10.5194/acp-18-10483-2018, 2018a.

Wang, H., Lu, K., Guo, S., Wu, Z., Shang, D., Tan, Z., Wang, Y., Le Breton, M., Lou, S., Tang, M., Wu, Y., Zhu, W., Zheng, J., Zeng, L., Hallquist, M., Hu, M., and Zhang, Y.: Efficient $\mathrm{N}_{2} \mathrm{O}_{5}$ uptake and $\mathrm{NO}_{3}$ oxidation in the outflow of urban Beijing, Atmos. Chem. Phys., 18, 9705-9721, https://doi.org/10.5194/acp18-9705-2018, 2018b.

Wang, M., Zeng, L., Lu, S., Shao, M., Liu, X., Yu, X., Chen, W., Yuan, B., Zhang, Q., Hu, M., and Zhang, Z.: Development and validation of a cryogen-free automatic gas chromatograph system (GC-MS/FID) for online measurements of volatile organic compounds, Anal. Methods, 6, 9424-9434, https://doi.org/10.1039/C4AY01855A, 2014.

Wang, T., Tham, Y. J., Xue, L., Li, Q., Zha, Q., Wang, Z., Poon, S. C., Dubé, W. P., Blake, D. R., and Louie, P. K.: Observations of nitryl chloride and modeling its source and effect on ozone in the planetary boundary layer of southern China, J. Geophys. Res.-Atmos., 121, 2476-2489, https://doi.org/10.1002/2015JD024556, 2016.

Wang, X., Zhang, Y., Chen, H., Yang, X., Chen, J., and Geng, F.: Particulate nitrate formation in a highly polluted urban area: a case study by single-particle mass spectrometry in Shanghai, Environ. Sci. Technol., 43, 3061-3066, 2009.

Wang, X., Chen, W., Chen, D., Wu, Z., and Fan, Q.: Long-term trends of fine particulate matter and chemical composition in the Pearl River Delta Economic Zone (PRDEZ), China, Front. Environ. Sci. Eng., 10, 53-62, 2016.

Wang, X., Wang, H., Xue, L., Wang, T., Wang, L., Gu, R., Wang, W., Tham, Y. J., Wang, Z., Yang, L., Chen, J., and Wang, W.: Observations of $\mathrm{N}_{2} \mathrm{O}_{5}$ and $\mathrm{ClNO}_{2}$ at a polluted urban surface site in North China: High $\mathrm{N}_{2} \mathrm{O}_{5}$ uptake coefficients and low $\mathrm{ClNO}_{2}$ product yields, Atmos. Environ., 156, 125-134, 2017.

Wang, Z., Wang, W., Tham, Y. J., Li, Q., Wang, H., Wen, L., Wang, X., and Wang, T.: Fast heterogeneous $\mathrm{N}_{2} \mathrm{O}_{5}$ uptake and $\mathrm{CINO} 2$ production in power plant and industrial plumes observed in the nocturnal residual layer over the North China Plain, Atmos. Chem. Phys., 17, 12361-12378, https://doi.org/10.5194/acp-1712361-2017, 2017

Wen, L., Chen, J., Yang, L., Wang, X., Xu, C., Sui, X., Yao, L., Zhu, Y., Zhang, J., and Zhu, T.: Enhanced formation of fine particulate nitrate at a rural site on the North China Plain in summer: The important roles of ammonia and ozone, Atmos. Environ., 101, 294-302, 2015.
Wen, L., Xue, L., Wang, X., Xu, C., Chen, T., Yang, L., Wang, T., Zhang, Q., and Wang, W.: Summertime fine particulate nitrate pollution in the North China Plain: increasing trends, formation mechanisms and implications for control policy, Atmos. Chem. Phys., 18, 11261-11275, https://doi.org/10.5194/acp-18-112612018, 2018.

Xu, Z., Wang, T., Xue, L. K., Louie, P. K. K., Luk, C. W. Y., Gao, J., Wang, S. L., Chai, F. H., and Wang, W. X.: Evaluating the uncertainties of thermal catalytic conversion in measuring atmospheric nitrogen dioxide at four differently polluted sites in China, Atmos. Environ., 76, 221-226, 2013.

Xu, Z., Wang, T., Wu, J., Xue, L., Chan, J., Zha, Q., Zhou, S., Louie, P. K. K., and Luk, C. W. Y.: Nitrous acid (HONO) in a polluted subtropical atmosphere: Seasonal variability, direct vehicle emissions and heterogeneous production at ground surface, Atmos. Environ., 106, 100-109, 2015.

Xue, J., Yuan, Z., Lau, A. K., and Yu, J. Z.: Insights into factors affecting nitrate in $\mathrm{PM}_{2.5}$ in a polluted high $\mathrm{NO}_{x}$ environment through hourly observations and size distribution measurements, J. Geophys. Res.-Atmos., 119, 4888-4902, 2014.

Xue, L. K., Saunders, S. M., Wang, T., Gao, R., Wang, X. F., Zhang, Q. Z., and Wang, W. X.: Development of a chlorine chemistry module for the Master Chemical Mechanism, Geosci. Model Dev., 8, 3151-3162, https://doi.org/10.5194/gmd-8-3151-2015, 2015.

Yang, T., Sun, Y., Zhang, W., Wang, Z., Liu, X., Fu, P., and Wang, X.: Evolutionary processes and sources of high-nitrate haze episodes over Beijing, Spring, J. Environ. Sci., 54, 142-151, 2017.

Yue, D., Zhong, L., Zhang, T., Shen, J., Zhou, Y., Zeng, L., Dong, H., and Ye, S.: Pollution properties of water-soluble secondary inorganic ions in atmospheric $\mathrm{PM}_{2.5}$ in the Pearl River Delta region, Aerosol Air Qual. Res., 15, 1737-1747, 2015.

Yun, H., Wang, T., Wang, W., Tham, Y. J., Li, Q., Wang, Z., and Poon, S. C. N.: Nighttime $\mathrm{NO}_{x}$ loss and $\mathrm{ClNO}_{2}$ formation in the residual layer of a polluted region: Insights from field measurements and an iterative box model, Sci. Total Environ., 622-623, 727-734, 2018.

Zhang, R., Wang, G., Guo, S., Zamora, M. L., Ying, Q., Lin, Y., Wang, W., Hu, M., and Wang, Y.: Formation of Urban Fine Particulate Matter, Chem. Rev., 115, 3803-3855, https://doi.org/10.1021/acs.chemrev.5b00067, 2015.

Zhou, W., Zhao, J., Ouyang, B., Mehra, A., Xu, W., Wang, Y., Bannan, T. J., Worrall, S. D., Priestley, M., Bacak, A., Chen, Q., Xie, C., Wang, Q., Wang, J., Du, W., Zhang, Y., Ge, X., Ye, P., Lee, J. D., Fu, P., Wang, Z., Worsnop, D., Jones, R., Percival, C. J., Coe, $\mathrm{H}$., and Sun, Y.: Production of $\mathrm{N}_{2} \mathrm{O}_{5}$ and $\mathrm{ClNO}_{2}$ in summer in urban Beijing, China, Atmos. Chem. Phys., 18, 11581-11597, https://doi.org/10.5194/acp-18-11581-2018, 2018. 